\title{
FLAPPERS TO RAPPERS: CRIMINAL LAW IN 1921 AND 1996
}

\author{
WAYNE N. RENKE*
}

This article examines the changes that have occurred in the area of criminal law over a seventy five year period, namely 1921-1996. It focuses on three areas - interrogation of accuseds, liability for culpable homicide and the use of victim impact statements. The history of the voluntariness rule with respect to confessions is thoroughly explored. Furthermore, effect of the Charter of Rights and Freedoms on both the interrogation of accuseds and the liability for culpable homicide is discussed. The author concludes by briefly canvassing the policy issues surrounding victim impact statements and their effect, if any, on sentencing.
L'auteur examine les changements survenus en droit criminel de 1921 à 1996. Il se penche sur trois domaines : l'interrogatoire des accusés, la responsabilité en cas d'homicide coupable et l'utilisation des déclarations des victimes. L'historique de la règle concernant la nature spontanée ou volontaire des confessions est soigneusement étudié. De plus, l'effet de la Charte canadienne des droits et libertés sur l'interrogatoire des accusés et la responsabilité en cas d'homicide coupable est abordé. L'auteur conclut par une brève revue des questions stratégiques entourant les déclarations sur les répercussions sur la victime et leur incidence éventuelle sur la détermination de la peine.

\section{TABLE OF CONTENTS}

I. INTERROGATION $\ldots \ldots \ldots \ldots \ldots \ldots \ldots \ldots \ldots \ldots$. 81

A. VOLUNTARINESS $\ldots \ldots \ldots \ldots \ldots \ldots \ldots \ldots \ldots$

B. THE CHARTER: RIGHT TO COUNSEL,

RIGHT TO SILENCE . . . . . . . . . . . . . . . . 89

II. LIABILITY FOR HOMICIDE $\ldots \ldots \ldots \ldots \ldots \ldots \ldots \ldots 100$

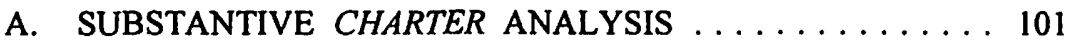

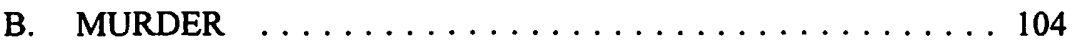

C. MANSLAUGHTER $\ldots \ldots \ldots \ldots \ldots \ldots \ldots \ldots \ldots$

D. CONCLUSIONS RESPECTING

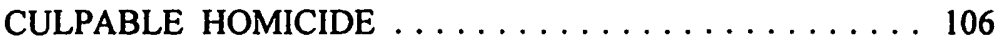

III. VICTIMS, VICTIM IMPACT STATEMENTS,

AND OFFENDERS $\ldots \ldots \ldots \ldots \ldots \ldots \ldots \ldots \ldots \ldots \ldots \ldots$

A. VICTIM IMPACT STATEMENTS $\ldots \ldots \ldots \ldots \ldots \ldots 107$

B. CLASHES WITH PROFESSIONALLY-

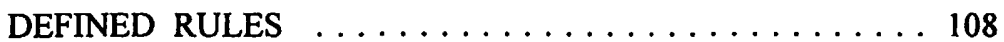

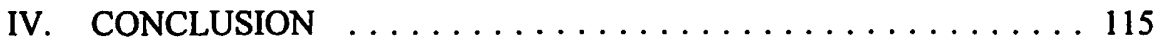

Suppose that one sunny September afternoon in 1996, Dr. Who, the well-known time traveller, arrived at the University of Alberta Law Centre in his vessel, the Tardis. He had a passenger, a student of the law, who had journeyed from 1921 to survey the workings of criminal law in the mid-1990s. The student realized that the criminal law is of vast expanse - indeed, that there is no such thing as "the criminal law," but many statutory and common law rules addressing crime and its contexts, causes, and effects. The student knew that across this broad and flexible legal terrain myriad changes would have occurred over seventy-five years. The student hoped that we would assist in 
tracing strands of similarity and difference in the past and modern responses to crime, in determining whether past and modern responses operate in different legal frameworks, and in evaluating, at least in microcosm, whether the modern responses to crime might be "improvements" over those of the past. To focus inquiry, the student proposed consideration of three legal aspects of the response to adult crime - (I) the interrogation of accuseds, (II) liability for culpable homicide, and (III) the use of victim impact statements in sentencing.

What the student learned is that our modern criminal law, despite backsliding and unevenness, is leaving a period of professionalized positivism respecting individual rights, and has begun to turn on a richer notion of personhood than the criminal law of the 1920s. This has led to increased recognition of the rights of accused persons - and the rights of persons victimized by crime.

\section{INTERROGATION}

In the 1990s as much as the 1920s, accuseds' incriminating admissions to State authorities have been important bases for convictions. Canada has never eliminated the plea of "guilty," and has never required the State to prove guilt entirely without reliance on confessions. The confession is simply too certain and expeditious an evidential foundation for conviction to be given up (why admit guilt if not guilty? what more need be proved if guilt is admitted?). Nonetheless, the English and North American judiciary has for centuries looked askance at confessions. Confessions are taken outside the direct supervision of the court, in private, generally in the precincts of police; the accused, often a person of little or no intellectual or financial resource, is pitted against burly, wily and experienced State investigators. The accused is in the grip of the psychology of powerlessness. The police are invested with surplus power. The police come to court claiming that the accused has confessed. Yet who can be sure of what has taken place in the privacy of the police confessional? Rules have therefore been developed to ensure that confessions are elicited only in acceptable circumstances. The rules reflect tensions between multiple policy objectives: obtaining convictions, obtaining true and reliable evidence, protecting accuseds against self-incrimination, preserving accuseds from State coercion and frame-ups, disciplining improper police behaviour, ensuring fair treatment of accuseds, and respecting the rights and dignity of accuseds.' ${ }^{\prime}$ Some of the rules have been set by judges. These are the "voluntariness" rules. Some of the rules have been established as constitutional principles under the Canadian Charter of Rights and Freedoms. ${ }^{2}$

\section{A. VOLUNTARINESS}

The student found the modern voluntariness rules a mixture of the old and new. The rules remain, in general outline, those of 1921 . The rules have developed, modestly, to provide increased protection for accuseds. The developments, however, are new wine 
in old skins. The developments tend to stress the importance of individual accuseds' subjectivity in a manner foreign to the old rules.

In typical English fashion, the voluntariness rules have defined the right by the remedy. That is, the voluntariness rules are, primarily, exclusionary rules applicable at trial. If State authorities engaged in prohibited pre-trial conduct and induced a statement, the sanction against the State is the exclusion of the accused's statement in trial proceedings. An effect of the rules is to deter improper pre-trial behaviour by State authorities. Both trial and pre-trial effects were traditionally conceptualized without reference to any "rights" of the accused. In a sense, the accused played a secondary role in the voluntariness rules. The most important role was played by judges, who supervised police conduct and ensured that reliable evidence was placed before the court. We see here a professionalised positivism. The judges - legal professionals determined when statements were excluded, thereby determining, in practice, the rights of accuseds.

The increased reliance on evidence of the accused's subjectivity in the voluntariness rules bespeaks a growing judicial recognition that accuseds' interests deserve protection; that accuseds' rights, not issues of the availability of remedies, are paramount. To make out our claim, we and the student first explored the similarities between the 1920s and 1990s approaches to voluntariness, then discussed some of their differences.

\section{1921 and 1996: Continuity}

By 1914, the basic framework of the voluntariness rules had been established by the House of Lord's decision in Ibrahim:

\footnotetext{
It has long been established as a positive rule of English criminal law, that no statement by an accused is admissible in evidence against him unless it is shewn by the prosecution to have been a voluntary statement, in the sense that it has not been obtained from him either by fear of prejudice or hope of advantage exercised or held out by a person in authority. ${ }^{3}$
}

The Ibrahim case and its approach to voluntariness were expressly endorsed by the Supreme Court of Canada in the 1921 Prosko decision. ${ }^{4}$ The student found many of the voluntariness rules to be familiar terrain. The basic structure of voluntariness issues remains in 1996 as it was in 1921: it is first determined whether the person to whom the statement was made was a "person in authority"; it is then determined whether the statement was made "voluntarily" — in particular, whether the statement was the "involuntary" product of inducements made by the person in authority.

In 1921 as in 1996, the Crown bears the evidential burden on the voluntariness issue. The Crown must go forward with evidence to establish voluntariness as a condition

3 Ibrahim v. The King, [1914] A.C. 599 at 609, Lord Sumner [hereinafter Ibrahim]; R. v. Thompson, [1893] 2 Q.B. 12 (Cr. Cas. Res.) at 15-7, Cave J. [hereinafter Thompson].

$4 \quad$ Prosko v. The King (1922), 66 D.L.R. 340 (S.C.C.); The Honourable J. Sopinka, W. N. Lederman Q.C. \& A.W. Bryant, The Law of Evidence in Canada (Toronto: Butterworths, 1992) at 330. 
precedent to the admissibility of the confession. ${ }^{5}$ Voluntariness is determined by the trier of law, the judge, rather than the jury; hence, voluntariness is established in a voir dire within a trial, in the absence of the jury. ${ }^{6}$ The determination of voluntariness is made in all of the circumstances surrounding the taking of the accused's statement. If the statement is admissible, the whole of the statement, including both inculpatory and exculpatory parts, must be tendered if the Crown seeks to rely on any part of it, and the whole of the statement is admissible against the accused as proof of its contents.

The "person in authority" condition of the old law remains in the modern; it has not been abandoned, as some might have predicted or desired. ${ }^{8}$ The old and modern descriptions of "person in authority" are similar. A "person in authority" is a person capable of influencing or entitled to influence the course of criminal litigation against an accused, including the arrest, detention, examination, and prosecution of the accused; persons in authority include magistrates, constables, and private persons, if likely to commence prosecutions privately. ${ }^{9}$ Persons in authority also include others who hold out inducements, if persons in authority were present and acquiesced to the making of the inducements - the others were, in effect, agents of the persons in authority. ${ }^{10}$

1920s authorities: Ibrahim, supra note 3 at 690; Thompson, supra note 3 at 16; Sir James F. Stephen, A Digest of the Law of Evidence, 8 th ed. by Sir Herbert Stephen \& H.L. Stephen (London: MacMillan and Co., 1907) \$22; S. L. Phipson, The Law of Evidence, 6th ed. (Toronto: Carswell, 1921) 264; C. S. Kenny, Outlines of Criminal Law, 9th ed. (Cambridge: Cambridge University Press, 1918) 394; 1990s authorities: A. F. Sheppard, Evidence (Toronto: Carswell, 1988) $\$ 950$; Park v. The Queen, [1981] 2 S.C.R. 64 at 69, Dickson J. [hereinafter Park]; Erven v. The Queen, [1979] I S.C.R. 926 at 931, Dickson J. [hereinafter Erven]. Kenny and Phipson were prescribed texts in Criminal Law and Evidence in the first years of the Faculty of Law at the University of Alberta: Legal Archives Society of Alberta, Law Society of Alberta, fonds 5, volume 63, 59; volume 66, 121, 123. Thanks to Rick Klumpenhouwer, archivist of the Legal Archives Society of Alberta, for his assistance with archival research.

Ibid.; Sopinka, Lederman \& Bryant, supra note 4 at 353,356 . Even if a confession is held to be admissible, the accused may still attack the evidence in trial on the basis that, for example, it was not in fact made; if made, it was untrue; or if made, it does not have the meaning asserted by the Crown.

7 Sopinka, Lederman \& Bryant, ibid. at 361; P. K. McWilliams Q.C., Canadian Criminal Evidence, 3d ed. (Aurora, Ontario: Canada Law Book, 1996) at 15-86, 88; Whittle v. The Queen (1994), 92 C.C.C. (3d) 11 at 26 (S.C.C.), Sopinka J. [hereinafter Whittle]. R. v. Sweryda (1987), 34 C.C.C. (3d) 325 at 330 (Alta. C.A.), Laycraft C.J.A. [hereinafter Sweryda].

1920s authorities: Kenny, supra note 5 at 395; Phipson, supra note 5 at 265; Stephen, supra note 5 at $\$ 22 ; 1990$ s authorities: $R$. v. A.B. (1986), 50 C.R. (3d) 247 at 256 (Ont. C.A.), Cory J.A., leave to appeal to S.C.C. ref'd. 50 C.R. (3d) xxv [hereinafter A.B.]; McWilliams, supra note 7 at 15-40; $R$. v. Wells, [1996] B.C.J. No. 1233 at 927 (C.A.) (Q.L.), Hinds J.A. [hereinafter Wells]. 1920s authorities: R. v. Taylor (1839), 173 E.R. 694 at 695, Patteson J.; Kenny, supra note 5 at 397; Phipson, supra note 5 at 265; 1990 s authorities: $R$. v. A.B., supra note 9 at 256; McWilliams, supra note 7 at $15-39$. 
Under both old and modern law, the inducements must have concerned fear of prejudice or hope of advantage. " The prejudice avoided or advantage sought must have been of a "temporal" character, not of a religious, spiritual, or moral character. ${ }^{12}$

Old and modern authorities contemplate that there must be some causal link between the inducement and the confession. The confession must be "due to" the inducement. ${ }^{13}$ The effect of an inducement may, however, be dissipated by a lapse of time,${ }^{14}$ or by an intervening caution or appropriate warning against making incriminating statements: $:^{15}$

[I] the threat or promise under which the first statement was made still persists when the second statement is made, then it is inadmissible. Only if the time-limit between the two statements, the circumstances existing at the time and the caution are such that it can be said that the original threat or inducement has been dissipated can the second statement be admitted as a voluntary statement. ${ }^{16}$

In the 1920 s and the 1990s, as a matter of practice and judicial encouragement, before taking statements, the police should warn suspects that they have the right to remain silent, and that they are not obliged to say anything to the police - but if they choose to do so, what they say may be used as evidence against them. ${ }^{17}$ In the 1920 s and the 1990s, however, the failure to provide the caution does not render a confession involuntary. It is only one factor to be considered in determining whether or not a confession was given voluntarily. ${ }^{18}$

1920s authorities: $R$ v. Warickshall (1783), 168 E.R. 234 at 235 (Cr. Cas. Res.), Nares J. [hereinafter Warickshall]; Kenny, supra note 5 at 395; 1990s authorities: Park, supra note 5 at 66. 1920s authorities: $R$ v. Jarvis (1867), 10 Cox C.C. 574 at 576 (Ct. Crim. App.), Kelly C.B.; Kenny, supra note 5 at 395, 396; Stephen, supra note 5 at $\$ 22 ; 1990$ s authorities: $R$. v. Belliveau (1985), 58 A.R. 334 at 339 (C.A.), Lieberman J.A.; Sopinka, Lederman \& Bryant, supra note 4 at 341 ; McWilliams, supra note 7 at 15-43.

1920s authorities: Kenny, supra note 5 at 395; Phipson, supra note 5 at 268; Stephen, supra note 5 at $\$ 22 ; 1990$ s authorities: $R$. v. Hobbins, [1982] I S.C.R. 553 at 557, Laskin C.J.C. [hereinatter Hobbins]; Horvath v. The Queen (1979), 44 C.C.C. (2d) 385 at $426-9$ (S.C.C.), Beetz J. [hereinafter Horvath]; E.T. v. The Queen (1993), 86 C.C.C. (3d) 289 at 304 (S.C.C.), Sopinka J. [hereinafter E.T.].

is 1920s authorities: Phipson, supra note 5 at 268; 1990s authorities: McWilliams, supra note 7 at $15-67$.

16 R. v. Smith, [1959] 2 Q.B. 35 at 41, Lord Parker C.J.; quoted with approval by Beetz J. in Horvath, supra note 13 at $426 ;$ E.T., supra note 13 at 304.

$17 \quad 1920$ s authorities: Stephen, supra note 5 at $\S 24 ; 1990$ s authorities: McWilliams, supra note 7 at 15-47.

is Ibid.; 1920 's authorities: Kenny, supra note 5 at 398; 1990 's authorities: Boudreau v. The King, [1949] S.C.R. 262 at 267, Kerwin J.; R. v. Ball (1978), 22 A.R. 270 at 273 (S.C.T.D.), Quigley J.; R. v. Esposito (1985), 49 C.R. (3d) 193 (Ont. C.A.), Martin J.A., leave to appeal to S.C.C. refd. 50 C.R. (3d) xxv; McWilliams, supra note 7 at 15-65, 66. A recent and startling development in the "caution" rules is found in $R$. v. Hanuse, [1996] A.J. No. 615 (Q.B.), Veit J. (Q.L.): "Where a video-taped statement is taken after a traditional caution, in circumstances where the accused is not told that the statement is being video-taped, the ensuing statement is 'off the record' and does not meet the common law standards of having been obtained freely and voluntarily": ibid. at I 3a. 
A surprising weakness of the voluntariness rules in the 1920s and the 1990s has been their failure to extend protections against police artifice. A confession is not inadmissible under the voluntariness rules, even if obtained by such underhanded means as lies made to the accused about other evidence or by violating promises of secrecy or confidence. ${ }^{19}$ Apparently, the old law even allowed the police to obtain confessions from intoxicated suspects. ${ }^{20}$ Both old and modern voluntariness rules allow the police to obtain confessions by trickery, as by posing as the cell-mate of a suspect, so long as the tricks do not amount to "dirty tricks."21

An enduring and remarkable feature of the voluntariness rules has been their boundedness. While a confession may be involuntary and pro tanto inadmissible, real evidence discovered or evidence of observations of an accused's conduct derived from the confession are admissible. ${ }^{22}$ Furthermore, those portions of the involuntary confession confirmed by the real evidence or observations are admissible, since those portions, at least, must be true. ${ }^{23}$

\section{1921 and 1996: Differences}

We showed the student that despite the similarities between the past and current voluntariness rules, over the last seventy-five years, many facets of the rules have been re-interpreted to favour accuseds. The standard of proof which the Crown must satisfy has been increased. By the mid-1970s (at the latest), Canadian courts established that the Crown must discharge its evidential burden by proving voluntariness beyond a reasonable doubt. ${ }^{24}$ The ambit of the rules has been expanded, in three main ways. First, while early authorities limited the voluntariness rules to inculpatory statements and to statements not manifestly voluntary, the Supreme Court has applied the rules both to inculpatory and exculpatory statements, and to elicited and "spontaneous"

1920s authorities: Kenny, supra note 5 at 398; Stephen, supra note 5 at $\S 24 ; R$ v. Derrington (1826), 172 E.R. 189; 1990s authorities: McWilliams, supra note 7 at 15-57.

$R$ v. Spilsbury (1835), 173 E.R. 82 at 82-3, Coleridge J.; Kenny, supra note 5 at 398; Stephen, supra note 5 at $\S 24$. Modern authorities suggest that, at least where the level of intoxication is significant, the confession would be inadmissible since it would not be the product of an operating mind: $R$ v. Richard (1980), 25 B.C.L.R. 29 at 34 (C.A.), Nemetz C.J.B.C.; McKenna v. The Queen, [1961] S.C.R. 660 at 663, Kerwin C.J.C.

1920s authorities: Stephen, supra note 5 at $\$ 24 ; 1990$ s authorities: Rothman v. The Queen, [1981] 1 S.C.R. 640 at 664, 666, Martland J. [hereinafter Rothman]; McWilliams, supra note 7 at 15-58. Warickshall, supra note 11 at 235; Kenny, supra note 5 at 398; $R$ v. Leatham (1861), 8 Cox C.C. 498 at 501, 503 (Q.B.), Crompton J.; $R$ v. Jenkins (1822), 168 E.R. 914 (Cr. Cas. Res.); Phipson, supra note 5 at 270; 1990s authorities: $R$. v. Wray, [1971] S.C.R. 272 at 296, Martland J. [hereinafter Wray]; Sopinka, Lederman \& Bryant, supra note 4 at 367; McWilliams, supra note 7 at $15-94$.

1920s authorities: Phipson, supra note 5 at 270; Stephen, supra note 5 at $\S 22 ; 1990$ s authorities: Wray, ibid. at 296; R. v. St. Lawrence (1949), 93 C.C.C. 376 at 391 (Ont. H.C.), McRuer C.J.H.C. at 391; McWilliams, supra note 7 at 15-94.

Sopinka, Lederman \& Bryant, supra note 4 at 359; see the 1960's authorities cited by McWilliams, supra note 7 at $15-79$. 
statements. ${ }^{25}$ Second, early authorities had emphasized that the voluntariness rules only pertained to persons charged with crimes or suspects. ${ }^{26}$ The modern Canadian view appears to be that the voluntariness rules are engaged whether or not the person from whom the statement was taken was in custody, was charged, or was about to be charged. ${ }^{27}$ Third, the old authorities emphasized that the inducement leading to the statement must have been connected to the charge in question, and not to some collateral matter. This restriction has been rejected in England and Canada. ${ }^{28}$

Most importantly, judges in the 1990s are far more concerned with the subjective state of the accused than were judges in the 1920s. The subjectivity of the suspect has become increasingly important in the assessment of voluntariness:

The strength of mind and will of the accused, the influence of custody or its surroundings, the effect of questions or of conversation, all call for delicacy in appreciation of the part they have played behind the admission, and to enable a Court to decide whether what was said was freely and voluntarily said, that is, was free from the influence of hope or fear aroused by them. ${ }^{29}$

Evidence of accuseds' subjective states is now considered not only on the traditional issues of whether a particular person was a "person in authority" and whether any words used were an "inducement," but on issues not considered by the courts in 1921 - whether the accused's statement could not be considered "voluntary" because of the accused's psychological state at the time of making statement, because the accused lacked an adequate appreciation of the consequences of making the statement, or because of circumstances of "oppression."

The old authorities suggested that the test for determining whether a person was a "person in authority" was objective. Modern authorities have attempted to find a place for evidence of the accused's subjectivity, although the test has not been worked out in a satisfactory way. Some modern authorities plainly contend that the test is purely subjective: the issue is whether the accused did or did not believe that the person to whom the statement was made was a person in authority. ${ }^{30}$ Other authorities state that the test is subjective, but then qualify that test by adding a reasonableness condition or

R. v. Piché, [1971] S.C.R. 23 (exculpatory statements); McWilliams, supra note 7 at 15-5; Erven, supra note 5 at 935 ("spontaneous" statements). Statements made under statutory compulsion must also be proved to have been made voluntarily before being admissible: $R$ v. Bossman (1984), 15 C.C.C. (3d) 251 at 253 (Alta. C.A.), Belzil J.A.; Walker v. The King (1939), 71 C.C.C. 305 at $307-$ 8 (S.C.C.), Duff C.J.C.; Marshall v. The Queen (1960), 129 C.C.C. 232 at 235 (S.C.C.), Kerwin C.J.C.

$26 \quad$ Phipson, supra note 5 at 263; Stephen, supra note 5 at $\S 21$.

$27 \quad R$ v. Sweezy (1974), 20 C.C.C. (2d) 400 at 413 (Ont. C.A.), Martin J.A. at 413 . McWilliams notes that "Canadian cases do not seem to attach such importance to [the distinction between pre-charge and post-charge questioning] - why, it is not clear": McWilliams, supra note 7 at 15-52. 1920s authorities: Kenny, supra note 5 at 396; Phipson, supra note 5 at 266; Stephen, supra note 5 at $\S 22 ; 1990$ s authorities: Customs and Excise Commissioners v. Harz and Power, [1967] 1 A.C. 760 at 819-21 (H.L.), Lord Reid; McWilliams, supra note 7 at 15-44. $R$. v. Fitton, [1956] S.C.R. 958 at 962 , Rand J.

$30 \quad R$ v. Stewart (1980), 21 A.R. 300 at 308 (C.A.), McGillivray C.J.A.; see Wells, supra note 9 at I 42. 
by adding a condition that, as a matter of law or policy, certain persons are or are not persons in authority. ${ }^{31}$ In the Rothman case, Martland J. stated that the test is subjective, but some of the authorities he relied on imposed a reasonableness condition. ${ }^{32}$ In Rothman, in any event, the person was not a person in authority because the accused did not believe that he was. The case may be authority only for the proposition that a subjective belief that a person is a person in authority is a necessary condition for that status, not a sufficient condition. Sopinka, Lederman, and Bryant suggest that the modern test is a combined subjective/objective test. ${ }^{33}$ If their view is right (and we need not decide that here), the person in authority test would have two components. The accused must have believed that the person was a person in authority; and there must have existed reasonable grounds for that belief. ${ }^{34}$ What is clear is that the old voluntariness rules make incorporation of evidence of subjectivity difficult - hence the indeterminateness of the cases.

Under the old law, the determination of the nature of inducements was objective, rather than subjective. The issue was whether the words or actions, construed to have their natural and obvious meaning, gave the suspect reasonable grounds for supposing that by making a confession he or she would avoid some prejudice or gain some advantage. ${ }^{35}$ Once again, modern courts have not satisfactorily worked out the nature of the test. Again, the test for the inducement status appears to combine subjective and objective elements. Sopinka, Lederman, and Bryant suggest that the accused must have believed that the words in question were an inducement, and that reaction of the suspect to the purported inducement must have been reasonable in the circumstances. ${ }^{36}$ Their view accords with that of Laskin C.J.C. in Hobbins, where the Chief Justice opined that an accused's timidity or subjective fear of the police would not avail unless there were external circumstances brought about by the police that would render the accused's statement involuntary. ${ }^{37}$

We pointed out to the student that modern cases have expanded bases for findings of involuntariness beyond circumstances where authorities have excited fear of prejudice or hope of advantage. The notion of involuntariness has been developed in three main directions. First, modern authorities have recognized that a statement cannot be voluntary, despite the absence of inducements, if it was not the product of an "operating mind." Thus, an accused who was in a car accident and was suffering from

R. v. Pettipiece (1972), 7 C.C.C. (2d) 133 at 151 (B.C.C.A.), Branca J.A. [hereinafter Pettipiece]; Cory J.A., as he then was, held in the $A . B$. case that the test was subjective, but shortly after making this declaration, found that a person was not a person in authority, despite the accused's subjective belief that she was: supra note 9 at 257; see also Sweryda, supra note 8 at 333 . Rothman, supra note 21 at 664; referring to, inter alia, a paper by Freeman C.J.M and the Pettipiece case: supra note 31.

33 Sopinka, Lederman, Bryant, supra note 4 at 352; McWilliams, supra note 7 at 15-38.

34 This would make the person in authority test similar in form to the subjective/objective tests that must be satisfied for provocation or self-defence under s. 34(2) of the Criminal Code: the accused must in fact have (subjectively) had certain beliefs, but those beliefs must have been (objectively) reasonable in the circumstances. 
shock or physical injuries may have been incapable of providing a voluntary statement; a hypnotized accused or an accused reduced to emotional disintegration might also be judged not to have an "operating mind. ${ }^{.18}$ Other causes of a lack of an operating mind include mental disorder ${ }^{39}$ and intoxication. ${ }^{40}$ Second, some authorities have suggested that a statement may not be voluntary if the suspect was unaware of the consequences of making the statement, at least where that lack of awareness was caused by conditions such as intoxication or hypnosis, and not merely by ignorance of the law." Third, some authorities have held statements to be involuntary where they were given in "oppressive" circumstances, although the Canadian authorities have shied away from expressly identifying oppression as a distinct basis for the exclusion of statements. ${ }^{42}$ Statements have been excluded where suspects have been subjected to "ill treatment" or "improper pressure, ${ }^{143}$ as where a suspect's clothing was taken from him, and, several hours later, he was interviewed wearing only a blanket; ${ }^{44}$ or where the suspect was confined without charge, not fed for hours, left to listen to odd sounds coming from the room in which another person was being interrogated, and interrogated persistently by the police. ${ }^{45}$ Excessive, intrusive, prolonged cross-examination by the police in an interrogation may render a statement involuntary. ${ }^{46}$

Prompted by the Charter, judges have lately expressly recognized that the interests of accuseds support a general right to remain silent. Accuseds' rights under the voluntariness rules have been interpreted to be one subset of the rights subsumed under the right to remain silent protected under s. 7 of the Charter as an aspect of "fundamental justice." The voluntariness rules, at least in principle, have thus been constitutionalized: "While the confession rule and the right to silence originate in the

Ward v. The Queen (1979), 44 C.C.C. (3d) 498 at 506 (S.C.C.), Spence J.; Horvath, supra note 13 at 412 , Spence J.; Beetz J. at 424; Rothman, supra note 21 at 675.

R. v. Santinon (1973), 11 C.C.C. (2d) 121 at 124 (B.C.C.A.), Bull J.A.; McWilliams, supra note 7 at 15-25. The degree of functioning requisite for an operating mind is low: "the accused [must] have sufficient cognitive capacity to understand what he or she is saying and what is said. This includes the ability to understand a caution that evidence can be used against the accused": Whittle, supra note 7 at 31 .

See authorities at supra note 20; Clarkson v. The Queen (1986), 25 C.C.C. (3d) 207 at 214 (S.C.C.), Wilson J. [hereinafter Clarkson]. It is not an invariable rule that proof of mental disorder or intoxication demonstrates that a statement is inadmissible; these conditions must prevent the accused from having an operating mind.

Horvath, supra note 13 at 424, Beetz J.; Clarkson, supra note 40 at 215.

Hobbins, supra note 13 at 557; Sopinka, Lederman \& Bryant, supra note 4 at 344; McWilliams, supra note 7 at 15-13. The Rothman case, significantly, does not rule out oppression as a ground for a finding of involuntariness. Martland J. quoted the McLeod case, which concerned oppressive police conduct, and distinguished it; he did not rule that the case involved any error of principle: Rothman, supra note 21 at 675; $R$ v. McLeod (1968), 5 C.R.N.S. 101 (Ont. C.A.). Wong Kam-ming v. The Queen, [1980] A.C. 247 at 261 (J.C.P.C.), Lord Hailsham. R. v. Serack, [1974] 2 W.W.R. 377 at 378 (B.C.S.C.), Berger J.

$R$ v. Antoine (1982), 70 C.C.C. (2d) 140 at 148 (Man. C.A.), Huband J.A.

R. v. Precourt (1976), 39 C.C.C. (2d) 311 at 318 (Ont. C.A.), Martin J.A., leave to appeal to S.C.C. refd., 39 C.C.C. (2d) $311 \mathrm{n}$; Sopinka, Lederman, Bryant, supra note 4 at 348; see generally McWilliams, supra note 7 at $15-51,15-57,15-61$. 
common law, as principles of fundamental justice they have acquired constitutional status under s. 7 of the Charter." ${ }^{47}$

\section{Conclusions Respecting Voluntariness}

The student concluded - and we had to agree - that the modern voluntariness rules mark an uneasy co-existence between two different approaches to the supervision of interrogation. The old voluntariness rules, which still inform the current law, were concerned with objective police actions. It was not that judges of the 1920 s made some kind of mistake, and somehow simply overlooked species of involuntariness that may exist despite a lack of inducements. Judges of the 1920 s were simply not overly concerned with accuseds' perceptions of and reactions to interrogation. These judges were content to act in a sort of judicial-review-of-police-action capacity; they did not recognize the interests of accuseds as being the basis for judicial intervention to uphold rights. Accuseds received the relief judges considered appropriate, not the relief accuseds' interests demanded. The insertion into the old voluntariness rules of evidence of accuseds' subjectivities demonstrates increased concern for individuals' interests and the rights based on those interests. As judges have become more concerned with evidence of subjectivity, they have been drawn more tightly into orbit around individual rights. We had to await the Charter, however, before the individual could be given pride of place in the system of rules governing interrogations - although even under the Charter, the focus on individual rights is sometimes lost.

\section{B. THE CHARTER: RIGHT TO COUNSEL, RIGHT TO SILENCE}

The student saw that what was wholly new about the Charter in the criminal law was that it put the rights of accuseds first. Rather than having to infer accuseds' rights backwards from various legal rules and remedies, those rights became the beginning of analysis. Legal rules and remedies have come to be judged by whether they promote or hinder those rights. At least in theory (if not in practice) the Charter marks the end of the professional positivism of rights. No longer are accuseds' rights only what judges happen to say they are in particular rulings based on particular facts, or what Parliament happens to say they are in particular statutory provisions. Rather, accuseds' rights have constitutional pre-eminence over judicial and legislative rules. Certainly judges must interpret and apply these constitutional rights, and certainly judges shape the meanings of these rights, but these rights do have an objective, primary projection and protection in the Charter.

The Charter put the law of criminal evidence (and also, as we shortly explained to the student, the substantive criminal law) on a new footing. It erected a new analytical apparatus applicable to all evidential rules, both statutory and common law - even if the effect of the apparatus has been, frequently enough, to leave things as they were.

Whittle, supra note 7 at $24 ; R$ v. Hebert (1990), 57 C.C.C. (3d) I at 34 (S.C.C.), McLachlin J. [hereinafter Hebert]. In practice, the voluntariness rules have not been constitutionalized, in the sense that the evidential burden on voluntariness remains on the Crown. If the voluntariness rules were completely constitutionalized, the evidential burden would be allocated to the accused. 
It also generated evidential principles of its own, some supplanting the common law, some supplementing it. The Charter rights to counsel and rights to silence supplement the common law voluntariness rules.

Why, the student wondered, was the constitutional entrenchment of these rights necessary? Did some scandal occur that prompted increased protections for accuseds? We could point to no originating Canadian scandal, nor even to any patterns of police misconduct that goaded constitutional change - though sometimes misconduct, in more-or-less structural form, has occurred.

We invited the student to view these constitutional developments as part of the broader pattern of recognition of the rights of individuals. If we begin with the notion that the individual is the primary unit of moral and political worth, the interests of the individual should be promoted, and actions contrary to the interests of the individual should be scrutinized and justified before being permitted. The subjection of the individual to the processes of the criminal justice system as an accused is, generally, contrary to the individual's interests. The State should therefore be compelled to justify the subjection of an individual to these processes. It follows that the individual should not, at least until the State has made out a compelling case for intervention against the individual, be forced to establish that he or she should not be subjected to criminal processes. Moreover, the individual should not be compelled to assist the State in making out its case against himself or herself. The State should discharge its burden through its own resources, without conscripting, enlisting, drafting, or co-opting the accused into assisting in the assembly of the Crown's case against the accused. ${ }^{48}$ To force the individual to assist the State yields a double indignity: first, it relieves the State of its obligation to justify its actions against the individual; second, it forces that very individual to act against his or her own interests - it turns the self against the self. The constitutional protections of the right to counsel and the right to silence protect individuals from being forced to be accomplices of the prosecution.

\section{The Right to Counsel ${ }^{49}$}

We showed the student s. 10(b) of the Charter: "Everyone has the right on arrest or detention ... to retain and instruct counsel without delay and to be informed of that right." The student was impressed that this broad right to counsel was not determined by the courts (as by the United States Supreme Court in the Miranda ${ }^{50}$ decision), but by the express terms of the Constitution. This is an example of the Charter bringing rights to the court, rather than the court bringing rights to accuseds.

R. v. Jones (1994), 89 C.C.C. (3d) 353 at $367-9$ (S.C.C.), Lamer C.J.C.; R.J.S. v. The Queen, [1995] I S.C.R. 451 at 504, lacobucci J.

49 I have explored some of the topics to follow in greater detail in "By-Passing the Tell-Tale Heart: The Right to Counsel and the Exclusion of Evidence" (1996) 30:1 University of British Columbia Law Review 99.

so Miranda v. Arizona, 384 U.S. 436 (1966) at 487, Warren C.J. [hereinafter Miranda]. The Sixth Amendment to the United States Constitution does not expressly extend the right to counsel to pretrial stages of criminal litigation. 
The student wondered why we consider consultation with counsel so important during interrogations that it warrants constitutional mention. We responded that the right to counsel betrays an institutional suspicion - but not complete cynicism respecting the executive. (If the police could never be trusted to follow the law, then alleged confessions could never be safely admitted into evidence, regardless of constitutional rules. If the police could always be trusted to follow the law, neither the voluntariness rules nor the right to counsel would be necessary.) The right to counsel goes beyond the voluntariness rules, not only by imposing formulaic obligations on the police, but by putting the lawyer in the interrogation room. As Chief Justice Warren discerned in Miranda, the great effect of the right to counsel is to crack open the privacy of interrogations, to expose interrogations to legal scrutiny, and to stop interrogations by reminding accuseds of their right to remain silent. ${ }^{51}$ Counsel in interrogation rooms equalize the power imbalance between the police and accuseds, ensure that the police do not misconduct themselves in the taking of evidence, and protect accuseds' legal rights.

We pointed out to the student that while the right to counsel is not enjoyed only at trial, the right is triggered only upon a person becoming subjected to State power the person must be either arrested or detained. Under the Charter, "arrest" has tended to maintain its traditional meaning. ${ }^{52}$ "Detention," though, has been interpreted expansively, giving the Charter right broad ambit. "Detention" entails a measure of physical, psychological, or legal compulsion, constraint, or coercion by the State over the person, resulting in a deprivation of liberty, ${ }^{53}$ and includes submission or acquiescence to State authorities under a reasonable belief that the choice to do otherwise does not exist. ${ }^{54}$ If, however, a person is neither arrested nor detained, the s. 10(b) protections - unlike the voluntariness rules protections - are not available.

If a person is arrested or detained, the State authorities must (1) properly advise the person of his or her rights to counsel — these are the detainee's "informational" rights;

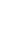

Ibid. at $455,467,471$.

An accused is arrested where a peace officer or other State authority "seizes" or touches a person's body with the intention to detain that person, or where the authority pronounces words of arrest and the person submits or acquiesces to the arrest: $R$. v. Whitfield (1970), 9 C.R.N.S. 59 at 60 (S.C.C.), Judson J.; B.P. Archibald, "The Law of Arrest" in V. M. Del Buono, Criminal Procedure in Canada: Studies (Toronto: Butterworths, 1982) 125 at 128.

$R$ v. Therens (1985), 18 C.C.C. (3d) 481 (S.C.C.), Le Dain J. (dissenting on other grounds) at 504, 505 [hereinafter Therens]; Schmautz v. The Queen (1990), 53 C.C.C. (3d) 556 (S.C.C.) at 571 Gonthier J.; Prosper v. The Queen, [1994] 3 S.C.R. 236 at 273, Lamer C.J.C. [hereinafter Prosper]; see $R$. v. Mellenthin (1992), 76 C.C.C. (3d) 481 at 486 (S.C.C.), Cory J.

34
Therens, ibid. at 505; Hufsky v. The Queen, [1988] I S.C.R. 621 at 632, Le Dain J.; Thomsen v. The Queen, [1988] I S.C.R. 640 at 649, Le Dain J.; Simmons v. The Queen (1988), 45 C.C.C. (3d) 296 at 315 (S.C.C.), Dickson C.J.C. [hereinafter Simmons]. In the Moran case, Martin J.A. provided a sensible, non-exhaustive list of subjective and objective factors relevant to whether a person is "detained": $R$ v. Moran (1987), 36 C.C.C. (3d) 225 at 258-9 (Ont. C.A.). See M. Rosenberg, "Selected Charter Issues (Part Two)" (1988) 3 M.V.R. (2d) 229 at 266ff. 
and (2) properly allow the person to exercise his or her rights - these are the detainee's "implementation" rights. 5

To perform their informational duties fully, the State authorities must, in a timely and comprehensible manner, inform a detainee of (a) his or her right to retain and instruct counsel without delay, (b) the availability of and means of access to Legal Aid counsel, and (c) the availability of and access to immediate but temporary "Brydges" duty counsel (a form of legal service available on a 24-hour per day basis, regardless of a detainee's financial status). ${ }^{s 6}$

If (and only if) the detainee indicates that he or she wishes to consult counsel, the implementation rights are engaged. ${ }^{57}$ The authorities must (a) provide the detainee with a reasonable opportunity to exercise the right to retain and instruct counsel without delay, and (b) cease questioning or otherwise attempting to elicit evidence from the detainee until he or she has had a reasonable opportunity to consult counsel (this is the duty to "hold off"). ${ }^{58}$ The student asked whether, if a detainee exercises the right to consult counsel and declines to provide a statement, the Charter prohibits the police from subsequently questioning the detainee. We had to admit that the duty to "hold off" is a duty to hold off only until the detainee has contacted counsel; subsequent questioning, so long as it does not involve the subversion of the right to counsel, is licit. $^{59}$

The student then asked whether, since the right to counsel is so important, we now recognize a constitutional right to have counsel provided if an accused cannot afford to retain counsel. No, we had to respond, no such constitutional right has been recognized, at least by the Supreme Court. Provinces such as Alberta do in fact have Legal Aid plans that allow the indigent to obtain counsel. In cases where indigent accuseds faced serious charges requiring complex defences but were unable to obtain State-funded counsel, some courts have imposed stays of proceedings pending the provision of counsel..$^{60}$ The student asked whether there is at least a constitutional right to Brydges duty counsel, since the first contact between an accused and the police must be very important. Regrettably, we had to admit, the present view of the Supreme Court is that there is, at least, no positive constitutional obligation imposed on the State under

Bartle v. The Queen, [1994] 3 S.C.R. 173 at 192, Lamer C.J.C. [hereinafter Bartle].

Ibid. at 195. Brydges duty counsel draw their name from the Brydges case, in which the Supreme Court discussed this type of legal service: $R$ v. Brydges (1990), 53 C.C.C. 330 (S.C.C.), Lamer J. [hereinafter Brydges].

Bartle, supra note 55 at 192.

$R$ v. Manninen (1987), 34 C.C.C. (3d) 385 at 391, 392 (S.C.C.), Lamer J.; Leclair and Ross v. The Queen (1989), 46 C.C.C. (3d) 129 at 134 (S.C.C.), Lamer J.; Brydges, supra note 56 at 340-1. Hebert, supra note 47 at 41.

R. v. Rain (1995), Stony Plain 30580187 P10101-102 (Alta. Prov. CL), Bradley P.C.J. (currently under appeal); $R$ v. Rowbotham (1988), 41 C.C.C. (3d) 1 at 69 (Ont. C.A.); $R$ v. D.Z., [1996] O.J. No. 1157 at 924 (Gen. Div.), Glithero J. (Q.L.); $R$ v. Sechon (1995), 104 C.C.C. (3d) 554 at 561 (Que. C.A.), Rothman J.A. 
s. $10(b)$ to ensure that free, preliminary legal advice is available on a 24-hour, on-call basis. ${ }^{61}$

We told that student that a detainee may waive either or both of the informational or implementation components of the right to counsel, although, in Lamer C.J.C.'s opinion, valid waivers of the informational component are rare. ${ }^{62}$ The student asked whether we require that a waiver form be executed, so that the issue of waiver does not become a credibility contest at trial between the police and an accused. We have no such requirement, we said. Well then, asked the student, since you have all this marvellous new and convenient technology - tape recorders and video equipment do you require that interrogations to be recorded, so you can be sure of what happened (at least during the period recorded)? Again, we had to reply, we do not. Neither, we added, do our courts draw an adverse inference from the failure to record interviews electronically, despite the ease with which the recording could be accomplished.

Perhaps, said the student, who was beginning to gain a somewhat mixed impression of our real concern for the right to counsel, further advances may be lodged under $\mathrm{s}$. 7 of the Charter. We were grateful for the diversion.

\section{Section 7 of the Charter and the Right to Silence}

The Supreme Court clearly advanced beyond the voluntariness rules' treatment of police trickery in its interpretation of 5.7 of the Charter. Section 7 provides that "[e]veryone has the right to life, liberty and security of the person and the right not to be deprived thereof except in accordance with the principles of fundamental justice." The Supreme Court has interpreted s. 7 protections to be available - as under s. 10(b) - only if the person is under control of the State.$^{63}$ In opposition to the voluntariness rules, if a detainee has indicated that he or she desires to consult counsel or to remain silent, the State cannot subvert that decision by utilizing either a State employee or agent to masquerade as a non-agent of the State and to interrogate or elicit incriminatory statements. ${ }^{64}$ Section 7 does not block all post-arrest spying on a detainee while he or she is in custody. If an undercover State operative were not to elicit information from the detainee but were merely a "fly on the wall," overhearing what the detainee was voluntarily saying either to others or even to that operative, the State would not be subverting the detainee's will, and the evidence collected by the State would be admissible.

Prosper, supra note 53 at 273; "To be absolutely clear, the issue of whether the Charter guarantees a right to state-funded counsel at trial and on appeal does not arise heren: ibid. at 266. See also R. v. Matheson, [1994] 3 S.C.R. 328 at 336, Lamer C.J.C.

Barile, supra note 55 at 203 . The difficulty with waiving the informational component of s. 10 (b) rights is that the detainee would have to know the information he or she was entitled to receive before waiving the transmission of that information: ibid. at 204. lacobucci J. 
The student asked whether section 7 of the Charter has also improved on the voluntariness rules by requiring the police to advise detainees of their right to remain silent. We had to admit that our courts have not, generally, required the police to provide this caution. ${ }^{65}$ The student remarked that our constitutional timidity flew in the face of Miranda, in which Chief Justice Warren held that "if a person in custody is to be subjected to interrogation, he must first be informed in clear and unequivocal terms that he has the right to remain silent. ${ }^{166}$ We conceded embarrassment.

The student then inquired into the evidential consequences of the State's violation of ss. 10(b) or 7 (assuming no challenge to any statutory or common law rule). The student thought that the rights to counsel and to silence must operate like the voluntariness rules. Surely, the student said, the State must prove that it complied with its obligations under s. 10(b) in particular and proof must be beyond a reasonable doubt; and if such proof is not forthcoming, evidence gathered in violation of constitutional rights must be automatically inadmissible. The student also trusted that the constitutional rules would improve on the voluntariness rules and exclude not only statements directly obtained from Charter violations, but evidence derived from those statements. Feeling somewhat uncomfortable, we said that no, the Charter does not work just that way, and we embarked on an explanation of s. 24 of the Charter.

\section{Evidential Remedies for Violations of Constitutional Rights: s. 24(2)}

\section{Section 24 of the Charter provides as follows:}

(1) Anyone whose rights or freedoms, as guaranteed by this Charter, have been infringed or denied may apply to a court of competent jurisdiction to obtain such remedy as the court considers appropriate and just in the circumstances. ${ }^{67}$

(2) Where, in proceedings under subsection (1), a court concludes that evidence was obtained in a manner that infringed or denied any rights or freedoms guaranteed by this Charter, the evidence shall be excluded if it is established that, having regard to all the circumstances, the admission of it in the proceedings would bring the administration of justice into disrepute.

Somewhat surprisingly, under s. 24 , the accused bears the primary burden of establishing entitlement to a remedy, such as the exclusion of evidence - the Crown does not have the burden of proving that rights were respected: s. 24(1) provides that "[a]nyone whose rights or freedoms ... have been infringed or denied may apply ... to (3d) 201 at 203 (P.E.I.S.C. App. Div.), Mitchell J.A.; $R$ v. Van Haarlem (1991), 64 C.C.C. (3d) 543 at 553 (B.C.C.A.), Toy J.A.; but see $R$ v. W.R.W. (1992), 15 C.R. (4th) 383 (B.C.C.A.) per curiam, where it is suggested that the police must give some indication to the accused of his or her right to remain silent (even if the formal words of a caution are not used). 
obtain such remedy as the court considers appropriate and just."168 As a consolation, the accused's burden is assessed only on the balance of probabilities standard. ${ }^{69}$ Procedurally, the allocation of the burden of proof entails that the accused must initiate and bear the evidential burden on a voir dire to exclude evidence. ${ }^{70}$

Subsection 24(2) is the sole route to the exclusion of evidence based on an infringement or denial of a Charter-protected right. The exclusion of evidence is not available as a remedy under s. 24(1). ${ }^{71}$ Subsection 24(2), again somewhat surprisingly, does not contemplate the automatic exclusion of evidence obtained through a Charter violation. Exclusion is available only if the accused can establish, inter alia, that the admission of the evidence would "bring the administration of justice into disrepute." The student found the denial of automatic exclusion odd. If Charter rights have been reasonably crafted, respecting them should create no practical difficulties - failure to respect them should not be tolerated. To the extent that the State is permitted to use evidence obtained through Charter violations, to that extent Charter protections are drained of practical significance. Again, if Charter rights have been reasonably crafted, there would seem to be no need for an additional balancing exercise concerning the exclusion of evidence obtained through Charter violations, with the exceptions that trivial or "harmless" (in a suitably defined sense) Charter violations should not require the exclusion of evidence. We explained that, regardless of what might have been abstractly desirable, s. 24 requires an accused to succeed on three main issues to justify exclusion. Each of these issues poses a significant practical hurdle for accuseds.

First, an accused must establish that his or her Charter rights or freedoms were infringed or denied. The accused may establish that the State authorities failed to perform their informational or implementation duties altogether; performed their duties in an inadequate or confusing manner (e.g. by mixing up the availabilities of Legal Aid and Brydges duty counsel or by describing the availability of Brydges duty counsel unintelligibly); or subverted or undermined the rights to counsel or silence by trickery or subterfuge. In response, the Crown may seek to establish on a balance of probabilities that the accused waived his or her right to counsel or right to remain silent. The standard is frequently said to be "high," and "very high" where the alleged waiver was not express but inferred from conduct. ${ }^{72}$ The Crown must establish that the accused clearly and unequivocally waived his or her Charter-protected rights with full knowledge of those rights. ${ }^{73}$ The main obstacles for the accused on these matters are evidential. Although the accused bears the burden of proof, defence counsel are typically loath to have their clients testify, even in the confines of a voir dire. In the

See Collins v. The Queen (1987), 33 C.C.C. (3d) 1 at 13-14, 16 (S.C.C.), Lamer J. [hereinafter Collins].

Collins, ibid. at 14, 16; Simmons, supra note 54 at 323.

R. v. Dwernychuk (1992), 77 C.C.C. (3d) 385 (Alta. C.A.), per curiam, leave to appeal to S.C.C. refd. [1993] 2 S.C.R. vii. The interplay between the Crown's voluntariness voir dire and the Charter voir dire have not yet been formally worked out.

Therens, supra note 53 at 508; Collins, supra note 68 at 13; Strachan v. The Queen (1988), 46 C.C.C. (3d) 479 at 494 (S.C.C.), Dickson C.J.C. [hereinafter Strachan].

Brydges, supra note 56 at 341; Bartle, supra note 55 at 206.

Clarkson, supra note 40 at 218. 
absence of an accused's evidence, establishing a Charter violation or resisting a Crown claim of waiver is difficult.

Second, if the Crown fails to establish waiver and the accused establishes a violation of his or her Charter rights, the accused must establish that the impugned evidence was "obtained in a manner that infringed or denied" the accused's Charter-protected rights. The accused need not establish a "causal link" between the Charter violation and the discovery of the evidence, although the presence of such a link may be good evidence that the impugned evidence had a non-remote connection to the Charter breach. ${ }^{74}$ The accused may establish that the violation and the evidence had a "temporal link"175 or "some connection or relationship," were "inextricably linked," or formed part of "a single transaction," 76 "chain of events," or the same "context." 77 A Charter violation may taint not only evidence proximately related to that violation, but subsequently obtained evidence.

Until recently, one might have been forgiven for having thought this was the issue on which the accused was most likely to succeed. The Supreme Court, however, has recently (it appears) tightened its approach to this issue. In Goldhart, despite the trial judge's finding of a causal connection between a Charter violation and evidence obtained from a witness, Sopinka J. held that the evidence was not obtained in a manner that infringed or denied a Charter-protected right. ${ }^{78}$ Sopinka $\mathrm{J}$. held that the trial judge erred by focusing on the causal relationship between the Charter violation and the evidence. The "entire relationship" between the two should have been considered, including whether there was a "temporal link" between the two. The connection between the violation and the evidence, in Sopinka J.'s opinion, was "too tenuous" or insufficiently strong. ${ }^{79}$ La Forest J., in dissent, properly pointed out that Sopinka J. deviated from preceding authority. ${ }^{30}$ The thrust of the jurisprudence had been that the "obtained in a manner" test was satisfied if the accused could establish a causal link between the violation and the evidence in question. The accused, though, was not required to prove a causal connection; the accused could still succeed if an

Therens, supra note 53 at 509; $R$ v. Goldhart, [1996] S.C.J. No. 76 at 9 36, Sopinka J. (Q.L.) [hereinafter Goldhart].

Strachan, supra note 71 at 498-99; R. v. Grant (1993), 84 C.C.C. (3d) 173 at 198 (S.C.C.), Sopinka J. [hereinafter Grant].

Black v. The Queen (1989), 50 C.C.C. (3d) 1 at 19 (S.C.C.), Wilson J.

Barlle, supra note 55 at 208, 209; Harper v. The Queen, [1994] 3 S.C.R. 343 at 353, Lamer C.J.C. [hereinafter Harper]; Strachan, supra note 71 at 498-99.

Goldhart, supra note 74 at $\uparrow 46$. The accused and the witness had operated a marijuana-growing business. The police seized certain real evidence and charged the accused and the witness under the Narcotic Control Act. The witness pled guilty in separate proceedings. The witness had been advised that the propriety of the search was being questioned, and his counsel advised against pleading guilty. The witness, though, had recently experienced a religious conversion, and desired to plead guilty. At the accused's trial, the real evidence was excluded as having been seized in violation of the Charter. The witness testified against the accused for the Crown. Despite finding a causal connection between the Charter violation and the witness' evidence, the trial judge admitted that evidence. The accused was convicted. The Ontario Court of Appeal held that the witness' evidence should have been excluded under s. 24(2) of the Charter.

Ibid. at If 42.

Ibid. at q1 52-8. 
otherwise sufficiently close connection could be established between the violation and the evidence. The jurisprudence did not require that both a causal connection and other links be established between the violation and the evidence. Neither did the jurisprudence contemplate that a causal link would be insufficient to satisfy the "obtained in a manner" test. ${ }^{81}$ As La Forest J. pointed out, the strength of the causal connection is relevant to further aspects of the s. 24(2) inquiry. ${ }^{82}$ The existence of a causal connection is one thing, and the strength of that connection is another. The two issues should be kept analytically separate. In any event, the effects of Sopinka J.'s decision are that accuseds must now prove not only a causal connection between Charter violations and evidence, but a "significant" or "non-tenuous" connection, and that more s. 24(2) applications shall be screened out at the "obtained in a manner" stage.

Finally, the accused must establish that, "having regard to all of the circumstances, the admission of [the evidence] in the proceedings would bring the administration of justice into disrepute." The Supreme Court has organized the relevant factors into three groups or subtests: (a) whether the admission of the evidence would have an adverse impact on trial fairness; (b) whether the violation of the accused's rights was serious; and (c) whether the exclusion of the evidence would cause greater damage to the repute of the administration of justice than the admission of the evidence. ${ }^{83}$

\section{a. Trial "Fairness"}

The first subtest draws Charter evidential remedies close to the voluntariness rules. The subtest involves consideration of whether the admission at trial of the evidence gathered through the Charter violation would be "fair." Very generally, the use of evidence is "fair" where the evidence would have been obtained by the State, regardless of the Charter violation (where the evidence would have been "inevitably" obtained).

Thus, where the evidence obtained was "confessional" - i.e., an oral or written statement or statement by conduct - typically the evidence would not even have existed absent the Charter violation (if the accused had been permitted to speak to counsel or if his or her right to silence had been respected, no admission would have been made). The State neither could nor would have obtained this evidence. The use of this type of evidence at trial, then, would be unfair to the accused. ${ }^{84}$ To the extent that confessional evidence is ordinarily excluded, Charter exclusion functions like the automatic exclusion under the voluntariness rules. Confessional evidence, however, is not always excluded. ${ }^{85}$ The Crown may establish that the accused would have

Presumably, the notion of causation operative under s. 24(2) was never a purely empirical "but for" notion of causation; rather, some policy standard of legal significance was presupposed by its application. Something like the Smithers test of causation, one might have thought, was always at work under s. 24(2). Ibid. at 958 .

The first two subtests are altemative grounds for the exclusion of evidence, subject to a balancing in favour of admission under the third subtest: Bartle, supra note 55 at 219. 
confessed, regardless of any Charter violation, as where the accused manifested an "irresistible desire" to confess. ${ }^{86}$ To this extent, even in the case of confessional evidence, Charter exclusion is a weaker remedy than the voluntariness rules.

Non-confessional evidence, such as "real evidence" or evidence of observations of accused, has tended to pose greater difficulties for exclusionary analysis, although the fairness principles remain the same. Real evidence, for example, does exist objectively, so there is at least the possibility that the State could have discovered it independently of a Charter violation. There is, however, a big difference between a logical "could" and a practical "would." Logically, the Crown "could" find any evidence whatsoever regardless of a Charter violation. If, though, the Crown would not have found the evidence absent the Charter violation, its admission at trial would be unfair. The Supreme Court has tended to find adverse impact on trial fairness where real or observational evidence was obtained by the "conscription" of the accused into the ranks of the prosecution - where, as a result of the Charter violation, the accused incriminated himself or herself by participating in the disclosure, production, or creation of the evidence. In such circumstances, as in the case of confessional evidence, the Crown would not have obtained the evidence absent the Charter violation. ${ }^{87}$

To the extent that the Charter exclusionary rules allow for the exclusion of evidence derived from illegal police conduct, the rules do appear more consistent than the voluntariness rules and, perhaps, morally superior to them as well. It should be kept in mind, though, that the exclusion of derivative evidence is not automatic.

\section{b. Seriousness}

Facts relevant to the second subtest are whether the violation was committed in good faith; was inadvertent or merely technical; was deliberate, wilful, or flagrant; ${ }^{88}$ or took place in truly urgent circumstances (not circumstances of contrived urgency, or urgency judged only by standards of police expediency) ${ }^{89}$ Another relevant factor is whether the State action was motivated by reasonable apprehensions of violent behaviour by the person from whom the evidence was obtained. ${ }^{90}$ The availability of other investigatory techniques and the possibility of obtaining the evidence without Charter violation are considered under this subtest. ${ }^{91}$ At least some early to middle-period jurisprudence indicated that violations were to be judged more serious if the authorities could have

Harper, supra note 77 at 354.

87 Burlingham v. The Queen (1995), 97 C.C.C. (3d) 385 at 405 (S.C.C.), Iacobucci J. [hereinafter Burlingham]. An issue that remains for the Supreme Court to decide is whether "conscription" is a necessary condition for trial unfairness (as argued by Doherty J.A. in $R$ v. Belnavis and Lawrence (1996), 107 C.C.C. (3d) 195 (Ont. C.A.) at 216ff); or whether trial unfaimess may be established in the absence of conscription, on the basis that the Crown would not have obtained the evidence, absent the Charter violation.

91 Collins, supra note 68 at 20. 
proceeded legally, but failed to do so (the authorities should have used legal means); ${ }^{92}$ or if the authorities had no legal means whatsoever to obtain the evidence (the authorities should have left the accused alone and not have attempted to obtain the evidence) ${ }^{93}$ Once again, the Supreme Court has recently tightened its approach to this subtest, making success under s. 24(2) more difficult for accuseds. In Silveira, the police entered a home without a warrant, in circumstances where a warrant could have been obtained; the police took this step to preserve evidence. ${ }^{94}$ Cory J. allowed that, on a case-by-case basis, this sort of Charter violation is acceptable, despite the existence of legal alternatives. ${ }^{95}$ In Evans, the Court was less subtle. ${ }^{96}$ The police conducted a warrantless "olfactory" search, in violation of s. 8 of the Charter. Sopinka $\mathrm{J}$. referred to numerous lawful investigatory techniques that were available to the police - surveillance of the home, infrared photography, utilities information searches. ${ }^{97}$ Sopinka J., however, considered these alternative investigatory techniques only on the issue of "discoverability" (finding that the evidence would have been "discoverable" absent a Charter violation), but did not consider whether the violation of the accuseds' rights was severe because the police had failed to utilize any of these techniques. ${ }^{98}$

\section{c. Effect of Exclusion}

The last subtest is the least developed in the jurisprudence and potentially the most dangerous to individual rights. The issue is whether the harm or cost to the repute of the administration of justice that would be caused by the exclusion of the evidence would outweigh the harm or cost that would be caused by the admission of the evidence. The long-term effect of the regular admission or exclusion of evidence of the type in question must be considered, not merely the short-term effect in the particular case in which the exclusion issue arises. ${ }^{99}$ The seriousness of the offence is a key factor for this subtest, but this factor has been interpreted in contrary ways by the Supreme Court. In some cases, the Court takes the view that where the charges are the most serious, accuseds' rights deserve the greatest respect. ${ }^{100}$ In other cases, particularly drug cases, the Court is prepared to weigh the seriousness of the charge against the exclusion of the evidence, as if the legal test is whether person-in-the-street would object to the exclusion of the evidence. ${ }^{101}$ Another relevant and similarly

Collins, supra note 68 at 20; Genest, supra note 90 at 404.

Kokesh, supra note 88 at 227.

Silveira v. The Queen (1995), 97 C.C.C. (3d) 450 at 500 (S.C.C.), Cory J. [hereinafter Silveira]. Ibid. at 501. In Silveira, the mitigating circumstances were that the police had decided, for tactical reasons, to effect an arrest of a suspect before searching his home; the worry was that word of the arrest would carry to the home before a search warrant could be obtained, and evidence in the home would have been destroyed. The police had not wanted to obtain the search warrant before effecting the arrest, for fear that the warrant would have been challenged as having been issued on the basis of "stale" evidence.

Evans and Evans v. The Queen (1996), 104 C.C.C. (3d) 23 (S.C.C.), Sopinka J.

Ibid. at 36.

Ibid.

Collins, supra note 68 at 17; Greffe v. The Queen (1990), 55 C.C.C. (3d) 161 at 183, 193 (S.C.C.), Lamer J.

Collins, supra note 68 at 21 ; Burlingham, supra note 87 at 408.

Grant, supra note 75 at 202. 
ambiguous factor is the importance of the evidence to the Crown's case. Generally, the Court's view is that the more important the evidence to the Crown's case, the less likely its exclusion. ${ }^{102}$ The contrary view, which has not obtained currency in the Court, is that the more important the evidence to the Crown's case, the less tolerable the tainting of that evidence by Charter violations, at least where those violations are not trivial.

\section{Conclusions Respecting Evidential Constitutional Rights}

The student admitted that from the standpoint of individual rights, the Charter has made great progress from the jurisprudence of the 1920s. Many of the decisions of the Supreme Court have been beneficial for accuseds, while not jeopardizing public safety or the administration of criminal justice. Nonetheless, the Court's embrace of individual rights seems, at times, lukewarm. Furthermore, in recent cases the Supreme Court seems intent on making the exclusion of evidence remedy less readily available to accuseds. We and the student shared the concern that constitutional rights could be reduced to mere rhetoric by too-frequent denial of exclusion under s. 24(2).

\section{LIABILITY FOR HOMICIDE}

Probably the most dramatic change in the substantive criminal law since 1921 has been the advent of judicial review of legislative and common law rules under the Charter. Charter review in the evidential context protects the dignity and rights of the individual from the depredations of the executive. In the substantive context, Charter review protects the dignity and rights of the individual from Parliament, the legislatures, and the courts. Once again, the Charter establishes individual rights as the fundament of analyses. Individual rights are not the positivistic product of legislative decree.

We explained to the student that Charter scrutiny of common law or legislative rules has two stages. First, the reviewing court assesses whether the rule limits, violates, or infringes a right protected by the Charter (such as freedom of expression, equality under the law, or the presumption of innocence). The person challenging the rule has the burden of establishing the infringement. If the infringement is established, the person supporting the rule (usually the State) may justify the infringement under s. 1 of the Charter. Section 1 provides that the rights and freedoms guaranteed by the Charter are subject to "such reasonable limits prescribed by law as can be demonstrably justified in a free and democratic society." Very generally, for a rule to be sustained under s. 1, the rule must serve a pressing and substantial governmental objective, and the means used by the rule to achieve that objective must be proportional to that objective; that is, the means must be rationally connected to the achievement of the objective, no other less intrusive legislative or common law means to achieve that for a conviction), but nonetheless held that the administration of justice would be brought into greater disrepute by the admission than the exclusion of the evidence: Kokesh, supra note 88 at 232. 
objective must be reasonably available (the rule must "minimally impair" Charter rights), and the benefits of the rule (its positive effects) must not be disproportional to its costs (its adverse effects). If the rule cannot be justified under s. 1 , pursuant to $s$. 52 of the Constitution Act, 1982, the rule is of no force or effect to the extent of its inconsistency with the Charter-protected right.

The student's particular concern was with liability for culpable homicide. We noted that the 1921 and 1996 statutory definitions of "homicide," "culpable homicide," "murder" and "manslaughter" were very similar. ${ }^{103}$ We pointed out, perhaps with a trace of superiority, that some of the murder provisions effective in 1921 have been declared unconstitutional, because they allowed for conviction on proof of constitutionally insufficient fault. The student was initially astounded by this apparent rout of Parliamentary sovereignty, but soon came to the conclusion that despite some substantive changes to the law and the erection of a very new analytical apparatus and rhetoric, aspects of Charter reasoning were familiar.

\section{A. SUBSTANTIVE CHARTER ANALYSIS}

Central to analyses of the culpable homicide legislation is $\mathbf{s .} 7$ of the Charter, which provides that "[e]veryone has the right to life, liberty and security of the person and the right not to be deprived thereof except in accordance with the principles of fundamental justice." The condition precedent to the application of $s .7$ is an actual or potential deprivation of life, liberty, or security of the person. Deprivation may be caused by the "stigma" attached to a conviction or the available penalties. ${ }^{104}$ Deprivation must be in accordance with the "principles of fundamental justice." The term "fundamental justice" is not defined in the Charter, although the Supreme Court has interpreted the legal rights listed in ss. 8 - 14 of the Charter to be instantiations of fundamental justice. These rights then, are aids to understanding its meaning. ${ }^{105}$ The Supreme Court has adopted the position - crucial to the criminal law - that "fundamental justice" is to be interpreted not only procedurally, as providing due process protections, but substantively. The content of legal rules, the elements of offences and defences, must also accord with fundamental justice. ${ }^{106}$ The student had three questions.

First, how does a court determine what the principles of fundamental justice might be? The Supreme Court has interpreted fundamental justice in light of the basic tenets and principles of the judicial process and the legal system generally, the traditions of common law, legislative developments, evidence of Parliamentary committee hearings

Criminal Code, R.S.C. 1906, c. 146, (hereinafter Criminal Code, 1906) s. 250 (homicide); s. 252 (culpable homicide - but infanticide was not named as a form of cuipable homicide at this time); s. 259 (murder); s. 262 (manslaughter); Criminal Code, R.S.C. 1985, c. C-46 [hereinafter the Criminal Code], s. 222(1) (homicide); ss. 222(2)-(5) (culpable homicide); s. 229 (murder); s. 234 (manslaughter).

$R$ v. Vaillancourt (1987), 39 C.C.C. (3d) 118 at 132 (S.C.C.), Lamer J. [hereinafter Vaillancourt]. Reference Re Section 94(2) of the Motor Vehicle Act (1985), 23 C.C.C. (3d) 289 at 301-302 (S.C.C.), Lamer J. [hereinafter Motor Vehicle Act Reference].

Ibid. at 301; R. v. Martineau (1990), 58 C.C.C. (3d) 353 at 359, Lamer C.J.C. [hereinafter Martineau]. 
and Parliamentary speeches, common law and legislation in other jurisdictions, international legal documents, and opinions of "jurists," including legal academics and philosophers such as H.L.A. Hart; and in light of implications drawn from other relevant Charter provisions.

Second, how does a court determine whether a particular offence accords with these principles? The Supreme Court has tended to examine three main factors - the interpretation of the offence, the "stigma" or "gravity" of the offence, and its penalty. The criminal act defined by the legislation must warrant both its description as a certain type of offence, and the stigma and penalty attached to that type of offence.

Third, how does a court determine the "stigma" or "gravity" of an offence? Regrettably, the Supreme Court has not provided anything like a satisfactory account of "stigma," yet the constitutionality of the culpable homicide provisions turns precisely on this notion.

Historically, the form of stigma analysis is not new. It did not originate only with the Charter. The student recognized a version of stigma analysis in nineteenth century English cases distinguishing "true crimes" from "absolute liability" offences. ${ }^{107}$ The more recent and precise foundation for the rhetoric is, we admitted, the decision of Dickson J., as he then was, in the Sault Ste. Marie case. ${ }^{108}$ Dickson J. made two important points in this case. First, Dickson J. indicated that "there is a generally held revulsion against punishment of the morally innocent."109 By "morally innocent," Dickson J. meant without "fault" in the sense of a (subjective) "mental element" accompanying an act. ${ }^{110}$ Second, Dickson J. referred to the "stigma" attending prosecution and conviction: "The argument that no stigma attaches does not withstand analysis, for the accused will have suffered loss of time, legal costs, exposure to the processes of the criminal law at trial and, however one may downplay it, the opprobrium of conviction."'11

The Dicksonian notions of moral evaluation and stigma have migrated into the Charter. The basic idea behind stigma analysis appears to be that particular criminal acts (as defined by Criminal Code provisions) are not normatively neutral, simply awaiting the attributions of blame and punishment we may happen to make. Rather, a particular act warrants or elicits a particular moral response, whereby blame is calibrated to the particular moral (or immoral) quality of that act. Stigma analysis presupposes not only that we can distinguish acts which warrant blame from those that moral transgression were considered in determining whether statutory interpretation dictated proof of mens rea for a bigamy offence: $R$. v. Tolson (1889), 23 Q.B.D. 168 at 175, 177. 
do not, ${ }^{112}$ but that we can distinguish different gradations of blame attributable to different acts. The student noted that stigma analysis, then, involves at base a rejection of positivism: the moral character of an act is not simply the product of our attribution of that character to the act; rather, the act's moral character is recognized or is presupposed in our moral assessment of the act. We conceded that the Supreme Court has not firmly grasped this implication of stigma analysis. Lamer C.J.C. has, properly, tended not to accept a "public opinion" approach to stigma, which would make stigma dependent not on the act itself but on what people simply happened to believe about the act. ${ }^{113}$ McLachlin J., however, has suggested that "stigma" is the judgment of opprobrium or blameworthiness attending conviction for criminal acts assessed by the general public, reflected in the judge's apprehension of the public's views. ${ }^{114}$ This approach is inconsistent with stigma analysis, and leaves the judgment of the moral character of acts dependent on shifting and difficult-to-discern public opinion.

Stigma analysis rejects positivism at yet another level: the criminal law is not just the set of rules we have happened to create to govern defined types of conduct. Under the Charter, the criminal law must (to some extent) track or mirror the moral responses to particular acts, so that the response of the criminal law is calibrated to the blameworthiness of particular acts. The criminal law should correctly classify a particular act - call it by its right name - and visit on that act the blame and punishment appropriate to that type of act. Stigma analysis yields the principles that (a) punishment must be proportionate to the moral blameworthiness of the offender; and (b) (the corollory that) causing harm intentionally must be punished more severely than causing harm unintentionally. ${ }^{115}$

Lamer C.J.C. has suggested that these principles accord with the dignity and worth of the person. ${ }^{116}$ How, the student wondered, can this be? We responded that to lump together morally different types of acts as a single offence is to stigmatize improperly persons having lesser fault as being responsible for crimes of greater fault. This improper stigmatization, in effect, ignores a person's true responsibility in favour of an imputed responsibility; the person is held responsible for what he or she did not do. The improper stigmatization, by itself, bespeaks a lack of concern with the person and his or her acts. Furthermore, improper stigmatization is typically done in service of some objective, such as deterrence: various acts receive the same legislative treatment to cause a variety of offenders to desist from (typically) dangerous acts. The person, then, is treated simply as a means to social ends. Again, the person's responsibility is ignored.

The Motor Vehicle Act Reference case tumed on the large distinction between moral guilt and moral innocence; the legislation deprived persons of liberty in violation of fundamental justice, because the legislation, which created an absolute liability offence, allowed the imprisonment of the morally innocent: Motor Vehicle Act Reference, supra note 105 at 310-11. Lamer J. ruled out reference to the "public interest" in S. 7 analyses: ibid. at 313.

$R$. v. Creighton (1993), 83 C.C.C. (3d) 346 at 375 (S.C.C.) [hereinafter Creighton], referring to "shocks to the public's conscience". I am indebted to A. Brudner, "Proportionality, Stigma and Discretion" (1996) 38 The Criminal Law Quarterly 302.

Martineau, supra note 106 at 360.

Motor Vehicle Act Reference, supra note 105 at 310. 
These abstract notions may be concretely applied respecting the offence of murder.

\section{B. MURDER}

The student offered two murder provisions for our analysis, ss. 259(d) and 260 of the Criminal Code, 1906:

259(d): Culpable homicide is murder ... if the offender, for any unlawful object, does an act which he knows or ought to have known to be likely to cause death, and thereby kills any person, though he may have desired that his object should be effected without hurting any one.

260: In the case of ... robbery ... culpable homicide is also murder, whether the offender means or not death to ensue, or knows or not that death is likely to ensue, $-\ldots$ if he means to inflict grievous bodily injury for the purpose of facilitating the commission of [robbery] ... and death ensues from such injury....

The penalty for murder in 1921 was death by hanging; today the punishment for murder remains severe. ${ }^{117}$ The stigma that attaches to a conviction for murder, in Lamer J.'s view, is also "similarly extreme."118 Life, liberty, and security of the person are indubitably engaged by these provisions. The real issues, then, are whether the blameworthiness of the acts described by these provisions warrant their stigmatization as "murder" and the available penalty.

Lamer J. took the view that because of the severe stigma and punishment attending a murder conviction, some special mental element with respect to the death caused by the accused must be established beyond a reasonable doubt before the accused may be convicted of "murder" - i.e., before the name "murder," with its attendant blameworthiness and punishment, may be attributed to the act in question. The special mental element that must attend the accused's causation of death is subjective foresight of death. ${ }^{119}$ The provisions offered by the student do not require proof of subjective foreseeability of death. Paragraph 259(d) allows for conviction on proof that the accused should have known that death would occur - that is, it allows for conviction on proof of only objective foreseeability. Section 260 allows for conviction if death was objectively foreseeable (assuming that the infliction of grievous bodily harm would entail the reasonable likelihood of death as a consequence) or even if death was not reasonably foreseeable - it allows for the possibility of conviction although even objective liability is not established. Since these provisions allow for conviction without proof of the constitutionally required mental element, they are inconsistent with Charter rights.

These provisions cannot be saved under s. 1 of the Charter. The objective of deterring killing, particularly in the course of the commission of other offences, is pressing and substantial. The legislation is rationally connected to that objective, since 
it penalizes those who kill in the course of committing offences. The legislation, however, fails the "minimal impairment" test. Other legislative means exist for penalizing and deterring offenders, which do not require conviction for murder. Lamer J. pointed out that accuseds could be convicted of manslaughter - "[b]ut stigmatizing the crime as murder unnecessarily impairs the Charter right."120

\section{MANSLAUGHTER}

The student then asked whether the Charter has required a complete reworking of the criminal law, since Lamer J. hinted in Vaillancourt that "[i]t may well be that, as a general rule, the principles of fundamental justice require proof of a subjective mens rea with respect to the prohibited act, in order to avoid punishing the 'morally innocent.'"121 In Martineau, Lamer C.J.C. had offered as a principle of fundamental justice that criminal liability for a particular result is not justified except where the actor possesses a culpable mental state in respect of that result. ${ }^{122}$ If Lamer C.J.C.'s position became the constitutional standard, the many criminal offences and defences that incorporate objective liability standards would be unconstitutional. The student asked whether manslaughter, in particular, has been constitutionally transformed into a subjective liability offence. After all, like murder, it involves culpable homicide and a potentially severe penalty. The stigma of being found to be a culpable killer, even under the manslaughter classification, must be very high. Alternatively, the student wondered whether stigma analysis requires legislative recognition of different gradations of fault in manslaughter - for example, between "voluntary" manslaughter (caused through provocation, or (perhaps) through recklessness) and "involuntary" or "negligent" manslaughter (where death was not intended or foreseen but was negligently caused). ${ }^{123}$

We had to respond that, in the Creighton case, the majority of the Supreme Court held that manslaughter is not constitutionally required to be a subjective liability offence. The Supreme Court has not yet suggested that manslaughter requires different gradations of offence provisions. The offence of manslaughter remains intact, in essentially its 1920s form. In interpreting fundamental justice in this context, McLachlin J. expressly referred to the international legal tradition allowing objective liability for manslaughter, a tradition extending past 1921:

We are here concerned with a common law offence virtually as old as our system of criminal law. It has been applied in innumerable cases around the world. And it has been honed and refined over the centuries. Because of its residual nature, it may lack the logical symmetry of more modern statutory

Vaillancourt, supra note 104 at 139; see Martineau, supra note 106 at 361-62.

Vaillancourt, ibid. at 133.

Martineau, supra note 106 at 360.

The Model Penal Code distinguishes murder, manslaughter (reckless homicide or homicide committed under extreme mental or emotional disturbance for which there is a reasonable explanation or excuse), and negligent homicide: see The American Law Institute, Model Penal Code, Tentative Draft No. 9 (Philadelphia: The American Law Institute, 1959) ss. 201.1(2), 201.2, 201.3, and 201.4; and Proposed Official Draft (Philadelphia: The American Law Institute, 1962), ss. $210.1(2), 210.2,210.3$, and 210.4 . 
offences, but it has stood the practical test of time. Could all this be the case, one asks, if the law violates our fundamental notions of justice, themselves grounded in the history of the common law? Perhaps. Nevertheless, it must be with considerable caution that a twentieth century court approaches the invitation which has been put before us: to strike out, or alternatively, rewrite, the offence of manslaughter on the ground that this is necessary to bring the law into conformity with the principles of fundamental justice. ${ }^{124}$

McLachlin J. held that the stigma attaching to a conviction for manslaughter was appropriate, and that the penalty for manslaughter is adaptable to the blameworthiness of the offender. ${ }^{125}$ McLachlin J. conceded that Lamer C.J.C.'s Martineau "symmetry" principle (mens rea applying to consequences) may be a general rule, but it is subject to significant exceptions - as in the case of manslaughter. She would not elevate this general rule into a constitutional principle, requiring manslaughter to be a subjective liability offence: "Fundamental justice does not require absolute symmetry between moral fault and the prohibited consequences. Consequences, or the absence of consequences, can properly affect the seriousness with which Parliament treats specified conduct." 126

Thus, while the student found the landscape of murder to have been altered by the Charter, manslaughter remains the offence that it was in 1921.

\section{CONCLUSIONS RESPECTING CULPABLE HOMICIDE}

The manner in which $s .7$ has been interpreted to promote individual rights by preventing wrongful convictions turns on an important but ill-thought out point of practical ethics: respect for the dignity of the person demands that a person be held criminally responsible for just that degree of fault for which the person is morally responsible. Perhaps, the student surmised, if the constitutional principle behind the Motor Vehicle Act Reference and Vaillancourt had been worked through better, the law of manslaughter would have lost its 1920 s form.

\section{VICTIMS, VICTIM IMPACT STATEMENTS, AND OFFENDERS}

The changes to criminal sentencing and punishment demonstrate some of the most manifest concern for the dignity and value of persons convicted of offences. Critical criminologists have warned us that the decline in physical punitiveness may not be purely progressive, but may mask more subtle and widespread means of social control. ${ }^{127}$ Nonetheless, the student felt that many changes since 1921 were objectively beneficial to offenders - capital punishment for murder was abolished in

Creighton, supra note 114 at 373.

Ibid. at 375-6.

lbid. at 378-80.

See M. Foucault, Discipline and Punish: The Birth of the Prison, trans. A. Sheridan (New York: Vintage Books, 1979); M. W. McMahon, The Persistent Prison? Rethinking Decarceration and Penal Reform (Toronto: University of Toronto Press, 1992). 
$1976 ;^{128}$ whipping was abolished in $1972 ; ;^{129}$ the meaning of imprisonment has been modified by successive waves of "correctional" evolution (from the "Big House," to the rehabilitative/correctional facility, to decarceration); ${ }^{130}$ the criminal law has come to rely increasingly on diversion, alternative dispute resolution, and non-custodial dispositions like probation. ${ }^{131}$

A less obvious but perhaps more significant change in the criminal law has been signalled by the use of "victim impact statements" in sentencing. To this point, we and the student had not been concerned with victims of crime. Their interests too, however, are being reworked in the law. Victims are now receiving greater recognition in the criminal justice system. The student worried that this development runs contrary to the developments in favour of accuseds' rights, and that the criminal justice system is in danger of being overwhelmed by angry and vengeful laypeople and their political allies. We conceded that the increased role of victims is attended by risk, but proposed an alternative account of the basis for this increased role. Victims' rights - as much or more than those of accuseds or offenders - had been set by professional decree; what is emerging more clearly in the criminal law is that victims, like accuseds and offenders, have dignity and value, and they bring these inherent rights to the criminal justice process. The stirrings of victims' rights may be detected in the victim impact statement provisions of the Criminal Code. These provisions, moreover, mark a change in approach to offenders that is more respectful of offenders' personhood.

\section{A. VICTIM IMPACT STATEMENTS}

The criminal law has always been concerned, in a fashion, with victims - without victims, there would be many fewer crimes and convictions. Victims have had, over these seventy-five years, at least some role in sentencing. The Criminal Code, 1906, like our own, contained, inter alia, provisions for compensation orders and the restitution of stolen property. ${ }^{132}$ While full-blown sentencing hearings involving viva voce evidence are rare, victims have been permitted to testify respecting the effects of

S.C. 1974-75-76, vol. 2, c. 105, ss. 4, 5; for a brief history of capital punishment in Canada, see I. Grant, D. Chunn \& C. Boyle, The Law of Homicide (Scarborough, Ontario: Carswell, 1994) 7-1. S.C. 1972 , c. 13 , s. 70 .

130 See J.W. Ekstedt \& C.T. Griffiths, Corrections in Canada: Policy and Practice (Toronto: Butterworths, 1984) 66-9; A.T. Scull, Decarceration - Community Treatment and the Deviant: A Radical View (Englewood Cliffs, New Jersey: Prentice-Hall, 1977); J.B.L. Chan \& R.V. Ericson, Decarceration and the Economy of Penal Reform (Toronto: Research Report of the Centre of Criminology, University of Toronto, 1981); M. Mandel, "The Great Repression: Criminal Punishment in the Nineteen Eighties" in K.R.E. McCormick and L.A. Visano, eds., Canadian Penology: Advanced Perspectives and Research (Toronto: Canadian Scholars' Press, 1992) at 189. Probation did not become available for adult offenders until 1921: D.W.F. Coughlan, "The History and Function of Probation" in R.C. McLeod, ed., Lawful Authority: Readings on the History of Criminal Justice in Canada (Toronto: Copp, Clark, Pitman, 1988) at 265-6. 
an offence. ${ }^{133}$ Victims may also provide testimony during trial, which, if relevant, could also be relied on in sentencing.

The victim impact statement provisions take an unorthodox approach to the introduction of victim evidence in sentencing. A victim impact statement is a filed document in prescribed form introduced following conviction. ${ }^{134}$ The statement is that of a "victim" - the person to whom harm was done by the offender or who suffered physical or emotional loss because of the offence, or if this person is dead, ill, or incapacitated, the spouse or relative of that person. The statement is to describe only "the harm done to, or loss suffered by, the victim arising from the commission of the offence" and not other matters. The statement is neither sworn nor adopted in testimony by the victim. Under recent amendments to the Criminal Code, judges must (not may) consider a filed victim impact statement in determining sentence or the discharge of an offender. ${ }^{\text {135 }}$

\section{B. CLASHES WITH PROFESSIONALLY-DEFINED RULES}

The student suggested that victim impact statements sit uneasily with standard (1) evidential and (2) sentencing principles. We responded that some of the apparent conflict is more apparent than real.

\section{Victim Impact Statements and Evidential Principles}

Victim impact statements appear to clash with evidential principles. The student pointed out that victim impact statements are unsworn, documentary hearsay; the offender has no immediate opportunity to confront or cross-examine the victim; the statements could also be characterized as self-serving evidence. Evidence of victim impact also seems to have a peculiarly irrefutable quality - the evidence of the impact is just what the victim says it was.

A response to these concerns is to view victim impact statements as evidential shortcuts. The statements' lack of formality should not be particularly troubling in many

R. v. Landry (1981), 61 C.C.C. (2d) 317 at 319 (N.S.S.C. App. Div.), MacDonald J.A.; R. v. Swietlinski, [1994] 3 S.C.R. 481 at I 40, Lamer C.J.C.; C. Ruby, Sentencing, 4th ed. (Toronto: Butterworths, 1994) 141-2, quoting Winneke C.J. in Webb, [1971] V.R. 147 at 150-1; see also D. A. Thomas, Principles of Sentencing, 2nd ed. (London: Heinemann, 1979) 372 at $n 3$ and The Honourable Judge D.R. Lanctot, "The Role of the Victim in Sentencing" National Seminar on Sentencing (Edmonton: Canadian Institute for the Administration of Justice, 16 October 1985) at 6-7; but see $R$ v. Robinson (1983), 38 C.R. (3d) 255 at 259-60 (Ont. H.C.), Reid J. Generally, outside of restitutionary and victim impact procedures, the victim has no technical standing in a criminal case and does not have an independent right to participate in sentencing: Re Regina and Antler (1982), 69 C.C.C. (2d) 480 (B.C.S.C.), McLachlin J.

Criminal Code, s. 722. The statement should be provided by the clerk of the Court to the offender or counsel "as soon as practicable after filing ... as directed by the court": Criminal Code s. 722.1 . The victim impact statement provisions of the Criminal Code as well as other sentencing provisions were amended by Bill C-41, S.C. 1995, c. 22, s. 6, proclaimed in force on September 3, 1996. 
cases. Sentencing proceedings very typically turn on the unsworn factual submissions of counsel for the Crown and defence. Victim impact statements simply allow the victim a voice in this arena. At least so long as the contents of the statements are uncontested, reliance on them should be no more troublesome than reliance on unsworn counsel submissions. If the contents are contested, evidence could be called in the ordinary way; the Criminal Code expressly provides that use of victim impact statements does not preclude the consideration of any other evidence respecting the victim. ${ }^{136}$ Evidence of victim impact is no more "irrefutable" than other evidence of subjective matters considered in criminal courts (such as the intention of an accused at a material time). It is true is that victim impact statements make the job of the defence more difficult. If the claims made in a statement are prejudicial to an offender, scarce defence resources may have to be expended to test those claims.

\section{Victim Impact Statements and Sentencing Principles}

Another clash occurs with the professional approach to sentencing. The student deployed four arguments against the use of victim impact statements: (a) their use serves irrelevant psychological purposes; (b) their use is unfair; (c) the statements are irrelevant; and (d) the statements improperly increase sentences.

\section{a. Psychological Effects}

Some proponents of victim impact statements justify the statements' use by a "catharsis" argument. Allowing victims to submit impact statements is said to allow victims to feel that they have had an opportunity to contribute to the penal process; to assist victims to overcome the feelings of "alienation" they may have from the criminal litigation parties and process; to assist in purging victims' anger; and to permit victims to achieve "closure." ${ }^{137}$ In response to such views, the student joined legal professionals in reminding us that the sentencing process is not therapy for victims. The sentencing process concerns the determination of the fit penalty for offenders, according to legal rules. The court room is no place for "feel good" psychology.

We had to agree that sentencing should not serve only as victims' therapy. The student, though, presented a false dichotomy: the choice is not between good psychological effects for victims and none at all. It is no objection to the use of victim impact statements that they have good psychological effects, so long as the use of the statements does not interfere with or impair the proper operation of sentencing hearings. If victim impact statements serve legitimate sentencing objectives, the fact that their use

Criminal Code, s. 722(3). The intersection of the ordinary rules of evidence with victim impact statements may produce results unanticipated by victims or victims' services workers. Not only might the victim be called as a witness, but so might be any persons who assisted in the preparation of the statement. Statements may be used against victims, as when a court compares the contents of the statement with other facts conceming the relationship of the victim and the accused, and draws an inference adverse to the victim's credibility: $R$. v. W.S. (1994), 90 C.C.C. (3d) 242 at 247 (Ont. C.A.), Finlayson J.A. 
benefits victims psychologically is simply a happy accident. The use of victim impact statements, though, cannot be justified solely by reference to psychological effects.

\section{b. Fairness to Offenders}

The student then argued that the use of victim impact statements is unfair to offenders, since the statements are not used in all cases: some offenders are jeopardized by the statements and some are not, on a random basis. Why should an offender face the penal repercussions of a victim impact statement, just because the jurisdiction in which the offence took place happened to have a victim impact statement program and the particular victim happened to complete a statement? Moreover, educated, literate, or eloquent victims will be able to prepare more effective descriptions of an offences' impact. Why should an offender face a more devasting statement, just because the victim happened to be educated, literate, or eloquent?

Offenders, however, seem ill-placed to complain of the arbitrariness of their contact with victim impact statements. If an offender has escaped judicial consideration of the effects of his or her crime, that offender was lucky. Offenders are lucky for many other reasons. Police officers may be unavailable for trial; the Crown prosecutor may have had insufficient time to review a file and may miss important facts or may overlook matters such as the criminal record printout stuck between two pages of the file; the judge may have been distracted or particularly lenient. The fact that some get what they deserve and others happen not to, is not an argument that none should get what they deserve. The proper response to the fairness argument is to advocate steps to ensure that victim impact statements are obtained and used in all appropriate cases.

The student suggested that the use of the statements was unfair in that the statements receive too much weight in sentencing. Ruby observed that "[n]o one can doubt that the victim impact statement creates more severe sentences by confronting the court with the effect of the crime upon the victim." 138 The statements create more severe sentences in part because they channel public pressure against judges. What judge could sentence leniently (had that been his or her inclination absent the statement) in the face of grave injury described in a victim impact statement?

These concerns are empirical and so we could only gesture towards proper responses. To begin with, there is no evidence that the use of victim impact statements in fact increases sentences - at least Ruby provides none. More importantly, there is no evidence that judges are particularly susceptible to excessive influence from victim impact statements. The more natural empirical assumption is that judges are capable of assigning the victim impact sentencing factor the weight it deserves, just as they are capable of giving the proper weight to other sentencing factors. In any event, sentences are reviewable on appeal. If a judge improperly gave too much weight to a victim impact statement and the sentence imposed fell outside the proper range for the offence, the court of appeal could provide a remedy. 


\section{c. Relevance}

The student argued that the preceding issues are derivative: the real issue is whether victim impact should be relevant at all in sentencing. The student wondered whether the use of victim impact statements was inconsistent with the principles of fundamental justice referred to in Martineau - punishment must be proportionate to the moral blameworthiness of the offender, and causing harm intentionally must be punished more severely than causing harm unintentionally. ${ }^{139}$ With respect to the latter principle, an offender may not have had any inkling of how his or her crime would have affected the victim, besides causing the injury defined through the actus reus of the offence. The offender and the victim may have been complete strangers. The offender may not have intentionally caused the impact that in fact resulted from the offence. Victim impact statements, then, should not be used to increase sentences. With respect to the former principle, the actual effect of a crime on a victim is a matter of chance. The victim may be strong and not unduly perturbed by the crime; the victim may be vulnerable, and his or her life may have been cast into disarray. How can an offender be held responsible for the chance products of his or her acts? Does not the focus on contingent effects obscure consideration of what the offender in fact did, of what the offender is actually responsible for? Yet another connected concern with the use of victim impact statements is that it appears to create classes of victims: those who are sensitive and literate can attest to greater harm than those who lack those qualities; the harm caused to the eloquent will have greater weight in sentencing than the harm caused to the less eloquent. ${ }^{140}$

We began our response with two clarifications. First, Martineau is distinguishable (in part) since the point at issue is not the classification of or attribution of stigma to an act, but the assessment of the appropriate punishment for the act. We must assume that the act has been properly "named" for criminal law and fundamental justice purposes. The issue, moreover, is not whether an offender should be blamed for what he or she did not do (constructive murder provisions blame a person for having committed murder when the offender did not commit a "murder," properly speaking); the issue is whether the offender should be blamed for the effects he or she in fact caused, even if the offender may not have intended those effects.

Second, no one should suggest that victim impact should be the sole basis for sentence determination. The effects of an offence are to be considered along with other factors to determine the fit sentence. If an offender knew that his or her crime would have devasting effects and devasting effects did occur, that offender should be punished

139

140

Martineau, supra note 106 at 360.

"Justice should not be based on the victim's eloquence, financial position, or family's presence but on the severity of the crime. It is no less a crime to attack one who is illiterate, poor or without a family. Why should one life be given greater value than any other?": A. Abramovsky, "Victim Impact Statements: Adversely Impacting Upon Judicial Fairness" (1992) 8 St. John's Journal of Legal Commentary 21 at 32; "Punishment responds to the wrong the offender commits, but not to the particular wrong as measured by victims willing to testify. Killing a homeless beggar is as great a wrong as depriving a family of a loved one": G.P. Fletcher, With Justice for Some: Victims' Rights in Criminal Trials (Reading, Massachusetts: Addison-Wesley, 1995) at 247. 
more severely than an offender who caused equivalent effects, but did not intend to do so (other things being equal). The use of victim impact statements does not violate the principle that those who commit harm intentionally should be punished more than those who commit harm unintentionally.

The student continued to press us: why should the chance effects of an offence be relevant to blameworthiness? Chance effects should not be attributable to the offender; they are not part of his or her act; he or she should not be responsible for them.

A positivistic response is that, legally, effects count. Two offenders may commit the same type of physical act. Because of the acts' effects, which to a greater or lesser degree lie outside of the actors' control, the acts may result in different convictions. One offender, for example, may be found guilty of an assault. The other might be found guilty of assault causing bodily harm, aggravated assault, or manslaughter. The $D e$ Sousa case, affirmed by McLachlin J. in Creighton, recognized that an offender may be held responsible for the fortuitous consequences of his or her act:

\begin{abstract}
Conduct may fortuitously result in more or less serious consequences depending on the circumstances in which the consequences arise. The same act of assault may injure one person but not another. The implicit rationale of the law in this area is that it is acceptable to distinguish between criminal responsibility for equally reprehensible acts on the basis of the harm that is actually caused. This is reflected in the creation of higher maximum penalties for offences with more serious consequences. Courts and legislators acknowledge the harm actually caused by concluding that in otherwise equal cases a more serious consequence will dictate a more serious response. ${ }^{141}$
\end{abstract}

If offenders should be held responsible for the actual effects of their offences, then victim impact statements are properly admissible as describing those actual effects.

We suggested to the student that taking effects into account in assessing blame is morally correct. We should weigh an offender's "moral luck" in judging his or her conduct. ${ }^{142}$ Taking "moral luck" into account affirms offenders' responsibility and agency. We reminded the student that we are neither omniscient nor omnipotent. As finite creatures we act in a world that imposes itself on our acts, generating unexpected consequences. Risk accompanies every human act. Holding offenders liable for the results of their conduct affirms our agency in our world.

No one suggests that a person should be liable for every effect caused by his or her actions in an empirical sense. The effects of our actions travel too far. An offender's position, however, falls within three constraints. First, the offender has committed some bad act. To reach the stage of sentencing, the offender must have been found guilty of an offence. The effects of that act are to be considered. Second, the effects of that act 
are restricted to effects on a definite person, the victim (where victim impact is considered as a sentencing factor). The victim cannot have been too remote from the offender's action, otherwise the offender would not have been found liable for the offence of harming this victim. Third, the weight of evidence of victim impact should be governed by a reasonableness criterion. An offender knows, or should know, that his or her acts could have a range of subjective effects on victims. A robbery of a home is not just a deprivation of property - it is an assault on the privacy, security, and dignity of the homeowners; a murder is not just a killing - it deprives a family or community of a soul. The pain or grief in fact experienced by victims may vary. Understanding and being able to anticipate the range of emotion is part of our equipment as ordinary humans. We should attribute this emotional appreciation to offenders. To do otherwise would be to suggest that they are less than fully human. If victim impact falls within the reasonable range of human response to a crime, an offender should be as responsible for that subjective response as for the physical consequences of his or her act. If a victim's response is unreasonable, though, an offender should not be held blameworthy, or blameworthy to the highest degree, for having produced that response.

The student's "creation of classes of victims" concern can be answered. The problem is not with differential injury caused by criminal acts, but with victims' differential ability to report similar injuries. Victims who are not educated, literate, or eloquent may receive assistance in preparing statements by victim services workers. The workers do not (or should not) supply words to victims, but help them talk about, understand, and relate in their own words the effect of crime. We should also take care not to make elitist assumptions about abilities to communicate. The impact of a crime can be described in simple language. The voice of a child may communicate as effectively as the voice of a multiple-degreed victim. Some, we had to concede, cannot speak for themselves, or have no one to speak for them (such as a murdered street person). These tragedies, though, do not militate against the use of victim impact statements. In a perfect world, victim impact could be equally addressed by all victims. Our inability to have victims speak in all cases should not prevent us from allowing victims to speak when they are able.

\section{d. Use of Victim Impact Statements}

The student was concerned that victim impact statements are instruments of vengeance. They are used to increase sentences. Victims, the student assumed with both Kenny and Ruby, are only interested in supporting severe punishments: "Most victim impact statements simply call for severe punishment...."143 The student urged that even if an offender may be responsible for the subjective effects of his or her actions, an enlightened and progressive sentencing system should not work towards greater punitiveness. Neither society nor offenders are best served by increasing periods of incarceration. testimonials by the angry and aggrieved could generate excessive sentences serving primarily the need for revenge": Fletcher, supra note 140 at 198. 
We had to point out to the student that it is not clear that "[m]ost victim impact statements simply call for severe punishment." Technically, none should do so, since the statement is not to be a sentencing recommendation but a description of only the impact of the offence on the victim. We find, in fact - and contrary to Ruby's supposition - that many victims who complete statements do not ask for harsh sentences for accuseds. ${ }^{144}$ Ruby himself refers to cases where victims have requested lenient treatment for offenders. ${ }^{145}$ Victim impact statements may be used not to increase, but to decrease the severity of the sentence that might otherwise have been imposed.

We were willing to agree with the student that longer sentences for offenders are not desirable, at least in many cases. We suggested, though, that victim impact statements should not be used only in the service of increasing or even decreasing sentences. The statements can be understood to serve better other objectives of more positive import to both offenders and victims.

Victim impact statements can be understood to properly serve the objective of causing the offender to take responsibility for his or her crime. This is the sentencing objective referred to in s. 718(f) of the Criminal Code: "to promote a sense of responsibility in offenders, and acknowledgment of the harm done to victims and the community." Victim impact statements confront the offender with the victim, the real person affected by the criminal act. By describing the effect of the crime, the victim shows the offender just what he or she has done. The statement is a statement: it is an act of communication by the victim to the offender. The tactic of showing an offender the consequences of his or her acts as a means to change the offender's behaviour is common outside the courtroom, in contexts as diverse as the teaching of children, the education of drunk drivers, and King/Gandhi-inspired civil disobedience. The courageous presupposition of this tactic is that the offender can be touched by a display of the effects of his or her acts. The offender must not be bereft of guilt, not bereft of sympathy for others, not bereft of the desire to be part of the community, not bereft of the capacity to comprehend and correct moral mistakes. The offender must simply have been mistaken or must have had an inadequate understanding of his or her acts. When the truth of the acts is manifested, the offender can realize his or her error and can choose not to harm others. A correlative presupposition of this tactic is that the victim believes all of these things about the offender. The victim, after all, is taking the step of seeking to communicate with the offender. The victim ultimately desires not vengeance, but reconciliation. If victims participate in the sentencing process, they can come to understand the offender. And often understanding brings forgiveness.

These reflections entail an approach to offenders that differs from that of standard sentencing. The offender is considered not to be an outlaw, a person outside the social contract, who must be destroyed, transported, or banished into the internal wilderness of the prison. Rather, the offender is considered to be a part of the community, a person who should be returned to or reclaimed by that community. The offender's value as a

145 See the Hardy, Clarke, and MacArthur cases described by Ruby (who does not assess their implications): Ruby, supra note 132 at 400. 
person is affirmed more strongly than in standard sentencing. The implication of these reflections is that victim impact statements should not serve the objective of securing longer, harsher sentences. The length of a sentence should not be affected by the presence or absence of a victim impact statement.

Of course, an offender may not care about what the victim has to say, either because of moral illness (should psychopathy be such) or because of ingrained selfishness. For this reason, the reconciliation response to criminal conduct cannot be exclusive. For those who are not inclined to enter into dialogue, recognize their error, and reform themselves, the prison has beds.

These reflections also lead to another objective served by victim impact statements, the objective of promoting victim participation in the criminal litigation process. Behind victim impact statements lies the idea that at least sentencing proceedings should be based on a more democratic, de-professionalised notion of criminal dispute resolution than the professionalised criminal law adversary system. The point of using victim impact statements is that the victim's voice counts, and should be heard - not as mediated by a lawyer or even a parole officer in a pre-sentence report - but as the victim's own voice. The victim should play some role in the proceedings. The victim takes back part of the reality of the offence from the State and its professional agent, the prosecutor. That reality is captured in the victim's ordinary language of pain, sorrow, and fear. The reality is not mediated by the professional legal vocabulary. The role of victims is, moreover, only the most visible part of the democratization of the criminal law. Behind victims are groups such as Victim Services Units, battered women's shelters, and rape crisis centres, lay groups who desire the law to make sense to lay people. Without a doubt, the de-professionalising tendencies of the victim impact statement program are what elicit the distaste of the legally-trained.

Again, lay participation could not replace the professional conduct of criminal litigation. The law is too complex and requires too much detachment from emotion and transient sentiment to be left completely to the lay community. The victim impact statement provisions, however, do point to a greater role in the criminal law for ordinary people than professionals have wished to imagine.

The victim impact statement provisions of the Criminal Code presuppose victims' rights. These are not rights to vengeance, to the destruction of the offender, to the negation of the offender's rights. The rights are to participate, to have a voice, to ensure that the real effects of crime are not elided by professional talk. Fundamentally, the right claimed by victims is that they not be forgotten.

\section{CONCLUSION}

The time had come for the student to return to the Tardis for the journey home. What, we wondered, would the student take from this visit to our past and the student's future? The student said that it would have been better for the world if, like the student, it could have skipped the horrors of the twentieth century to arrive at the recognition of the infinite value of the person, whether offender or victim. The student could see this recognition driving through our criminal law, like the shoot of a young plant; the 
student hoped that this recognition would not be choked by old authorities, old attitudes, or old professional pride. 